University of Louisville

ThinkIR: The University of Louisville's Institutional Repository

$1-1948$

\title{
The administration of the Lotta Fund for aiding discharged convicts at the Family Service Organization, Louisville, Kentucky, 1931-1946.
}

Cora Graf Lucas

University of Louisville

Follow this and additional works at: https://ir.library.louisville.edu/etd

Part of the Social Work Commons

\section{Recommended Citation}

Lucas, Cora Graf, "The administration of the Lotta Fund for aiding discharged convicts at the Family Service Organization, Louisville, Kentucky, 1931-1946." (1948). Electronic Theses and Dissertations. Paper 2005.

https://doi.org/10.18297/etd/2005

This Master's Thesis is brought to you for free and open access by ThinkIR: The University of Louisville's Institutional Repository. It has been accepted for inclusion in Electronic Theses and Dissertations by an authorized administrator of ThinkIR: The University of Louisville's Institutional Repository. This title appears here courtesy of the author, who has retained all other copyrights. For more information, please contact thinkir@louisville.edu. 


\title{
UNIVERSITY OF LOUISVIILE
}

\section{THE ADMINISTRATION OF THE LOTTA FUND FOR AIDING DISCHARGED CONVICTS AT THE FAMILY SERVICE ORGANIZATION LOUISVILLE, KENTUCKY, 1931-1946}

\author{
A Dissertation \\ Submitted to the Faculty \\ Of the Raymond A. Kent School of Social Work \\ In Partial Fulfiliment of the \\ Requirements for the Degree \\ Of Master of Science in Social Work
}

\author{
By \\ Cora Graf Lucas
}

Year

1948 
NAME OF STUDENT: Cora Graf Lucas

TITLE OF THESIS: The Administration of the Lot ta Fund for Alding Discharged Convicts at the Family Service Organization, Loulsvilie, Kentucky, 1931-1946

APPROVED BY READING COMMITTEE COMPOSED OF THE FOLLOWING KEMBERS:

Howell V. Williams

Chalrman

Katharine Belzer

DATE: January 27, 1948 


\section{ACKNOWLEDGMENT}

Appreciation is expressed by the writer to all persons assisting in this study. Particularly does she wish to acknowledge her gratitude to Miss Esther Taylor, Executive Secretary of the Family Service Organization, for her interest and helpfulness in making available case material and other material for this study; to Mabel Mason Ludwig, Controller, for her assistance with the financial figures of the Agency; to the executives of the other agencles administering the Lotta. Fund for their helpful information about their own experiences in 1 ts use; and to the trustees of the Lotta Crabtree estate for providing a copy of the section of the will dealing with the Ex-Convict Fund. 
TABLE OF CONTENTS

PAGE

LIST OF TABLES. . . . . . . . . . . . . v

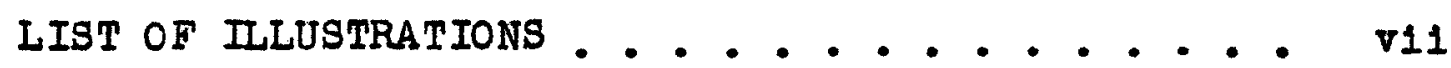

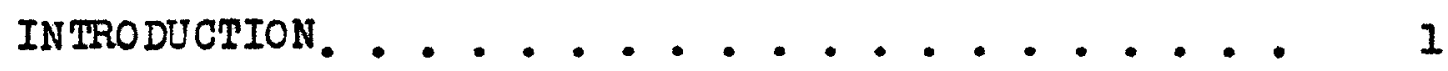
CHAPTER

I. HISTORICAL DEVELOPMENT AND AGENCY TRENDS. -

The Lotta Fund.

Family Service Organization Assumes a

New Service.

Depression Years and Use of the Fund, 1931-1932.

Clearer Definition of the Service, 1935-1939.

Service Related to the Individual, 1940-1946.

II. PRACTICE IN OTHER AGENCIES PARTICIPATING IN USE OF FUND. . . . . . . . . . . 43

Prisoners Relief Society of Washington, D. 0 .

The Prison Assoclation of New York.

Central Howard Association of Chicago.

III. CHARACTERISTICS OF PERSONS AIDED. . . .

52

Data from 92 case-records.

Penal Records.

Who is the Gient?

IV. USE OF THE FUND FOR RELIEF AND SERVICE. .

88

Coverage of Maintenance Items.

Use for Special Relief Items.

Use for Emergenoy Needs.

Forms of Relief - Giving: Cash,

Requisition, etc.

SUMMARY AND CONCLUSIONS ........... 102

APPENDIX ........................... 114

BIBLIOGRAPHY. ................. 118 


\section{LIST OF TABLES}

TABLE

PAGE

1. Number of Ex-Conv1cts Asa1sted by Yoar, As Compared to Total Caseload by Year, with Expenditure, Income and Yearly Balance of Lotta Fund. . . . . . . . . . . . . .

2. Data from $92 \mathrm{Ex}$-Convict Case-Records Ag to Sex, Race, Religion, Res 1dence, Family Status and Birthplace..

3. Educational Ratings and Training of $92 \mathrm{Ex}$-Conv1cts Assisted with Lotta Fund by the Family Service Organization. . . . . . . . . . .

4. Employment Records of 92 Ex-Conv1cts Asgisted with Lotta Fund by the Family Service Organization......

5. Age Range of 92 Ex-Convict Cilents Assisted with Lotta Fund by the Family Service Organization......

6. Extent of Diagnosed Mental Illness and Physical Illness or Handicap Among 92 Ex-Convict Clients

7. Extent of Verifications of Penal

Records and of Inclusion of

Material about Ex-Convict from

Penal Institutions. ...........

8. Number of Prison Sentences Per ExConvict Client with Accompanying Juvenile Delinquency, Ja11, or Workhouge Records............ 


\section{LIST OF TABLES}

TABLE

PAGE

9. Number of Offenses Committed Within

Listed Crime Classifications. . ...

10. Selection of Client by Agency as Shown by Number, Frequency, and Content of Interviews... . . ....

11. Nature of Referral Sources of 92 Ex-Conviot Cases Studied. . . . . . 83

12. Number of Other Family Service Organization Contacts by Ex-Convicts Studied.............. 86

13. Total Amounts of Lotta Fund Used from 1932-1946. . . . . . . . . . 90

14. Chief Forms of Relief from Lotta

Fund and Chief Recipients of Fund in $92 \mathrm{Ex}$-Convict Cases...... 
LIST OF TILUSTRATIONS

FIGURE

PAGE

1. Lotta Crabtree, A Portra1t from the ' 70 's.........

vi11 


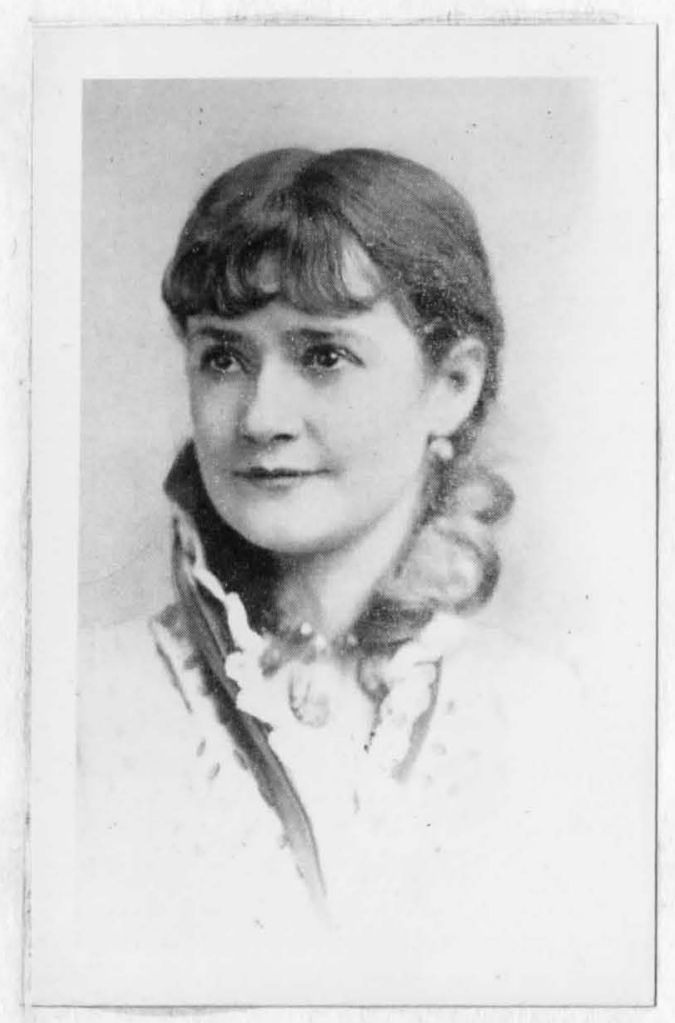

Lotta Crabtree - A Portrait from the 70's. 


\section{INTRODUCTION}

A beautiful and successful actress, Lotta Crabtree, Inoluded as part of her will, the following statement: "I have given much thought to the sad conditions of those who maj have erred in $11 f e$, both men and women, who suffered punishment therefor in our state prisons and reformatorles, and who find themselves after their release in an almost helpless condition in which to begin the world anew." To express the interest inherent in this statement she bequeathed to her trustees the sum of $\$ 100,000$, the income frow which would be for the purpose of alding discharged conviets. As soon as the estate was settled, in early 1931, Loulsville, Kentucky, was designated as one of seren clties to receive a share of this income. The mayor of Lou1sville--at that time Mr. William Harrison, an unusualiy progressive and socially-minded person--at once appointed a committee of three oltizens to supervise the fund and to find the proper agenoy to carry out the intent of the benefaotor. The President of the Committee, Mr. Grover Sales, was, and 18 again at this time, also the President of Family Service Organization, the community's 
private family agency; Mrs. Reuben Post Halleck, Vice President, was for years a board member of the Agency (deceased, 1946); Mr. Charles Roser, Seoretary-Treasurer, was one of the city offlcials in the Public Utilities Bureau. The Family Service Organization was selected as the agenoy to administer the Lotta Fund according to the terms of the will. At present the Committee still consists of Mr. Sales and Mr. Roser; as yet no one has been selected to 1111 the racancy oreated by: Mrs. Halleck's death.

The procedure set up to handle the Fund was, and 1s at present, as follows: Loulsville's share of the income from the Lotta Crabtree estate-areraging around $\$ 800$ per year-1s sent to Mr. Roser, who deposits the sum in the Committee's name and in turn sends the Family Service Organlzation a check for four or flve hundred dollars at irregular interrals. Any check draw on this fund by Mr. Roser must also be s1gned by Mr. Sales. In general, the total amount of the fund 18 given to the Family Service Organization for distribution, but occasionally Mr. Boser has given rellef directly to an ex-convict who may come to his offlos. (Due to a recent political party change in the city administration, Mr. Roser no longer holds an official position.) The occasions of such direct rellef-giving have been extremely rare, as 
the President, Mr. Sales, feels that the money should be given by a caseworker. Bren so, the chocks given by Mr. Roser must also be signed by $\mathrm{Mr}$. Sales.

The checks from Mr. Roser are deposited to the Family Service Organ1zation's Lotta Crabtree Special Fund and the money is used in the agency like any other spocial fund which is designated for a particular purpose1.e. the Veech Fund for milk, or money deposited by indiriduals for assistance to their relatives, etc. Family Service Organization's beginning use of the Fund was in May, 1931. From 1931 through 1946 the Family Servioe Organization has assisted 92 ex-convicts and often, as described in the present study, their families as well. During this flfteen year period, no study has been made of the 92 cases handled, nor has there been any over-all review of any kind made of the types of indiriduals assisted, services rendered exconvicta, duration of contact, etc. The first purpose of the present study 1s, therefore, to evaluate these cases, not primarily from a case-work point-of-view, since the Agency has no esteblished precedent for the handling of ex-conviots, but rather with the objective of seeing how accurately the administration of the Fund follows the purpose of the benefactor, as stated in that section of 
her will; how the criteria for the acceptance and continuance of these cases can be reconciled with some of the flexible, but defined, criteria for the handing of all other Family Service Organization cases, 1.e.: consideration of the ollent's legal residences eridence of some hopefulness within the ollent and his situation so that there 1s expectation of progress, as well as his participetion in effecting this progress, etc. Rellef to this latter group 18 adminlstered with continuous case work evaluation. On the other hand, the group of ex-conviot cases 1o the only one within the Agenoy where relief, in general, has been given without too much consideration of end results, since discharge or parole from local, state, or federal penal institutions, and financial need bave been, in practice, the only two requirements for the acceptance of such cases. Perhaps it w1ll be found, however, that some of the criteria for acceptance of any indiridual as a elient, have been applied to ex-convicts as well, since trained caseworkers tend to use generio principles in the handing of any and all individuale. Perhaps, as the history of the Agency's use of the Lotta Fund emerges through the study of 1 ts 92 cases, contradictions and confusion will inevitably be expressed as to whether or not an ex-convict is oategorically very much 
different from other olients. In 1 ts exposure to fifteen years' handling of this group, the Agency may show definitions of policy stated with more conviotion and assurance as the years go by and otaff skills 1ncrease.

The second purpose of the present study 18 to give a ploture from these 92 case records, of the types of cases handled through the use of the Ex-Convict Fund. It 18 hoped that the study will answer certaln questions, 1.e.: How old are these men and women? That were their offenses? Are they, in general, unattached indiriduals? What is the proportion between male and female olients? inite and Negro? Are these ex-convicts primarily residents of Loulsville or largely transiente? that 18 their background w1 th regard to education, training, employment? Are there many physically and mentaliy 11 individuals among the group? Do they seem to be recidivists?

The study should give us, further, a pleture of the origin of these cases. How did they originally come to the Family Service Organization? Who directed them to the Agency? How Iong did Family Service Organization carry the arses under the $\mathrm{Ex}_{\mathrm{x}}$-Conviot Fund? Were they reaccepted, as ex-convicts, a second or third time? on what basis? How was the rellef administered: to cover maintenance 1tems? For special needs: business equipment, 
transportation, union dues, etc.? For emergency needs, primarily met at the point of intake? As wage-relier? Were rellef negotiations made, for the most part, with the ex-convict directiy or with a member of the family? What community resources were used in handling the cases: psychiatric consultation, vocational adjustment, securing of recreational opportunities?

Cape in needed information may be determined: $I_{G}$ there unlformity in cheoking on the actual 1ncarceration, and what means have been used to do 80 ? Have reports been secured from the penal institutions and how have these been used?

As part of the beckground picture of the study, and subsidary to 1t, a brief survey of the practice of the seven other designated ofties' agencies in handing their portion of the Ex-Conviet Fund will be included, Insofar as It has been possible to obtain such information from the souroes. The reader may find it of some interest, also, to know something about the benefactor and her apparent motiration for setting aside such a generous sum for assistance to discharged convicts.

It 18 hoped that certain conclusions will ar1se from the study: By clarlfying the real motive for alding ex-convicts, and by examining the types of coses and 
Agency handling of these, can the Family Serrice Organization formulate for 1 tself a written polioy for administration of the Ex-Conviet Fund? Can the Agency determine, as part of this policy, the best use of the limited jearly share of the income, elther by a decision to help a greater number of indiriduals for shorter periods, or a fever number with greater assistance for a longer perlod? Can the Agency accept, as part of 1 ts stated function, the granting of relief on merely an emergency basis to relieve outside pressure for the ex-convict, without too much consideration of long-range results? Should there be selectivity In accepting ex-oonvict oases-on the basis of residence, consideration of the client's potentiality for rehabilitation, etc.? Has the opportunity to help in the rehabilitation of ex-conviots through the giving of rellef from a special fund been a "door-stop baby"--perhaps looked upon with mixed rejection and weloome aoceptance-jet capable of growing into a mature part of the Agency's group of services?

The method of making the present study involves geveral steps: Primarily, the study rests on detalled perusal of the entire number of ex-convict cases (92) carried by the Agency from 1931 through 1946. A comprehensive schedule was used with each case read. Reller 
Iigures were obtainable from the book-keoping department of the Agenoy, and Ageney flles of yearly statistics from 1931-1946 served as basis for tables. Use was made of s1x volumes of Agency files pertaining to the Ex-Conviot cases and containing memoranda to the staff from the Agenoy's Executive Secretary, who supervises the expenditure of the Fund within the Agenoy; required monthly narrative reports on Indiridual cases from the casoworkers to the Exeoutive Secretary, to be used in perlodic reports to the Treasurer of the Fund, Mr. Roser; correspondence to and from the Exeoutive Seoretary to the Treasurer and occasional correspondence to and from other sources. Indirldual interviews with the Executive Secretary, M18s Taylor, were very helpful. Letters have been written the executives of the seven other agencies who are reciplents of the yearly income from the estate of Lotta Crabtree, and the replies, which are on the whole understandably unsatisfactory in giving the comprehensive ploture desired, are included in the present study.

Many unsuccessful attempts were made to talk directly to the local Treasurer of the Fund, but the pressures of a busy position in the City Hall did not permit his granting the request for a personal interview.

A copy of the section of the will of Lotta Crabtree which deals with the Fund for Alding Discharged Conviots 
was requested and this was expeditely and most cooperatively returned, with an expression of interest in the otudy's beling done.

Al though case-material and Agenoy files form the bulk of the material used, some general baokground reading was done, both regarding some ourrent thinking in the rleld of criminology with special emphasis on treatment of conviots, and regarding the career and interests of the benefactor as these might have some bearing on her philanthropic bequests.

The present study is part of a series of studies already made of the history of the Agency and its services, Including a "History of the Family Service Organization" by Mrs. Bernice E1118; "Lay Participation in the Private Fam1ly Agenoy, Lou1sville, Kentucky, written by Miss Mildred Bateman; "A Study of the Family Service Organization, Loulsville, Kentuoky, in Reference to Intake", by Miss Marlan E. Prinz, and similar studies concerning the Agency's services to Maverly Hills Tuberoulosis Sanatorlum, working mothers' problems as shown by the Agenoy's cases, the history of the financing of the Agency, eto. Helpful assistance was secured through use of some of these theses for their bearing on the present material.

The present study combines the historical and statistical approaches in 1 ts adaptation of the source 
10

material. Throughout the text the terms "Lotta Fund" and "Ex-Convict Fund" are used interchangeably. 
CHAPTER I

HISTORICAL DEVELOPMENT AND AGENCY TRENDS

\section{The Lotta Fund}

It is highly concelvable that in the busy history of an agency, dedicated princlpally to the present and the future, many outlines of the background and original purpose of a special fund, like the "Lotta Fund for Alding Discharged Conviots" should be blurred. At one time the Ageney had, in its flles, magazine olippings of the famous Lotta Crabtree and her benerolent bequests. The material was used once in a caserorker's presentation to a lay committee of the Agency's services to ex-convicts. Misplaced or lost, the slight folder has been missing for some years, and rapld staff turn-over, increasing pressures and serlous concerns have seemingly erased the plcture of the benefactor even more. In the $31 x$ volumes of reports, letters, and Inancial statements-all Indioating consider ablo painstaking effort in giving an acourate accounting to the tressurer of expenditures for, and services to, the ex-conviet group from 1931-1946 and in attempting to refine teohniques of handling and reporting, there is no statement 
regarding Lotta Crabtree and probable interpretation of her will. This interpretation emerges, it seems, of itself, and becomes-at least in recent years-more self-consciously and studiously applied than perhaps the brief original Clause 9 of her will, recently secured, had intimated:

I give, devise and bequeath to my trustees horeinafter named in trust, the sum of one hundred thousand dollars, to be known as the "Lotta Fund for Alding Discharged Convicts," and to semi-annually pay over the income thereof pro rata to the Massachusetts Soclety for Alding Discharged Conv1cts, in Boston, Massachusetts, and to any society or socleties whose object it is to ald and endeavor to give employment to discharged convicts in the cities of San Francisco, in the state of California; St. Lou1s, in the state of Missour1; Chicago, in the state of IIIInols; New York, in the state of New York; Washington, in the Distriet of Columbia; Loulsvilie, in the state of Kentucky; and New Orleans in the state of Loulsiana. If there does not exist in any of the sald clties herein named a soclety for such purpose to receive the benefit of this fund, I authorize and direct $m y$ sald trustees to form in such city or olties a soclety for this purpose, to recelve 1ts pro rata share of the income of this fund.

(A) I make this bequest as I have always been, deeply appreclative of the generous support that was accorded me as an artist in all parts of the country in which I appeared before the pubilc with sincere desire to give pleasure and entertainment, and I desire to express my appreciation of the cordiality and good-will manifested toward me by showing my remembrance thereof by alding and encouraging the furtherance of some philantropic work that would be of real help to the unfortunate in some of our leading cities. I have given much thought to the sad conditions of those who may have erred in Iife, both men and women, who suffered punishment therefor in our state prisons and reformatories, and who find themselves after their release in an almost helpless condition in which to begin the world anew. 
It 18 perhaps of somewhat amall Importance that the or1ginal "Lotta" Is known only slightly as a descriptive term of the special fund, much less individualized as a real person. Her 1dentity 18 lost in the practical application of the fund she left. Undoubtedly the emphasis is best, jet some knowledge of the origin of the Fund and of Lotta Crabtree as a person lend interest and undeniable color to a service, of 1 tself interesting and colorful. "Lotta", as she insisted on belng informally addressed, personifled the successful actress of her era, ploneering, as she did, into a rather daring fleld-for women--of broad comedy, dancing, and singing. Born in New York in 1847, her early life was a parallel to the surging American scene of the "Gold Rush" perlod. Not many actual details of her life are known, but her career is traceable by the records of her successes and by storles of her friends. Constance Rourice weaves the fragments of her life into her account of the Gold Coast troupers ${ }^{l}$, and brings out facts Irom her research of that period that may have more than a colncidental bearing on Lotta Crabtreo's later philantroples. Tutored by an astute mother, who soon found she could not

IConstance Rourke, Troupers of the Gola Coast or the Rise of Lotta Crabtree Trew York: Harcourt, Brace and Company, 1928). 
depend on her handsome husband for support, and moved w1th her little daughter to Callfornia, Lotta Crabtree became, at the age of eight, a child performer who soon attained great popularity. Her early asBoclations were with the t1reless troupers of the period--actors who lived on the road and endured many physical hardships. Her audience was chlefly the rough crowd of miners and prospectors. Something of the violence of the perlod and of the motley audience are expressed in the desoriptive passage:

Sulcides were frequent then, as elsewhere in the gold regions. Men were constantiy drifting in who had suffered disappointment, lonelingss, cold, hunger, bejond the IImit of human endurance. ?

Lotta Crabtree achleved success in creating a close bond between herself and her audience, no matter how rough or exacting they might be, although in her personal relationshlps she was consistently lonely. She was often referred to as "Miss Lotta the Unapproachable". After unique success in the fleld of comedy and variety, she retired in her m1d-fort1es, and lived a solitary life unt1l her death in 1924. One senses the strength and w1ll of her mother's personality in all of her career. Her mother had become her manager and shrewdy handled thelr great wealth-consistently garnered since the days when the miners, in

1 In1d., p. 45 . 
their enthusiasm for the child actress, threw gold nuggets and pocket watches on the stage.

Since Lotta outlived her two brothers, and never wa marrled, there were no direct heirs to her estate. The Crabtress had continued to live a frugal existence despite their great wealth. Fabulous attempts were made to break Lotta Crabtree's will, but her solitary and personally circumscribed Iife was so patent that storles of a secret marriage and a mysterious child were easily disproved. Constance Rourke sums up the content of her will as follows:

The will which the gold-seekers tried to break had a noticeable character. Over half of Lotta Crabtree's fortune was given to a foundation for the relief of needy veterans of the Great War; she provided for the care of the sick in hospitals, and for prisoners on their emergence 1nto the world; she left money for an actorsi rellef fund; she created a fund for students of music, another for atudents of agriculture, for good cheer at Christmas, and for the promotion of laws against vivisection. She left money for the care of worn-out horses and stray dogs. The strands of many genuine interests appeared in her will: but an outstanding olrcumstance was clear. She made only a few small personal bequests. There could be no doubt that she preferred not to share that great heap of money-nearly four mililon dollars--with people whom she knew. The bulk of her estate went to strangers. The provisions were complicated; one hates to think of her toliling over them. It was perhaps a pity that her money had to be disposed of at all; her fortune should have become a legend like her mirth. Yet logic remains in that IInal document, from Lotta, who seldom bothered about logic. There was fitness in the circumstances that she gave her great rewards to strangers. From strangers she had galned them; and she seemed to have only conventional reasons for personal bequests. Few persons had become an essential part of her life, out 
of the multitude she had known..... So her will, with 1 ts effect of withdraval, its survey of distances, may, $s$ tand $a$ an emblem of $a$ long and bright efflorescence. 1

Thus "strangers" today both administer and recelve the investments of her fortune. It would, howerer, concelvably add a touch of warmth and apark of greater enthusiasm in the actual handing of the "Lotta Fund for Alding D1scharged Convicte", occasionally to remember the benefactor and her unreproving interest in people, whatever their origin, status, or destination.

Family Service Organization Takes Orer A New Service In May, 1931, Loulsville's first check from the Lotta Fund was deposited in the bank. The staff was not1fled about the existence of the special fund, although the original memorandum explaining 1 ts use cannot be located at present. Case loads were combed to suggest possible cand1dates for this assistance. Apparently, no more than a very general type of interpretation had been given the Agency as to the use of the Fund, and the staff was, to some extent, groping to fit the new service into 1 ts function, at an extremely pressing period. The new Fund meant additional money at a time when half the 1931 budget had already been spent, in March of that year. The Agency was trying to meet 
overwhelming demands for assistance in the communlty--demands already legitimately met in many citles of Loulsville's s1ze by publ10, tax-supported agenc1es. There was pressure of high case loads for the staff, and there was some initial slowness in the caseworker's becoming aware of the Fund as an additional resource-as the Executive Secretary's memorandum to the three district supervisors of July 11, 1931 Indicates:

W11l you please go over with your v181tors again the fam1lies where there are ex-conv10ts. We have $\$ 1100$ wo can draw for the care of ex-convicts and their fami11es. We are trying to lind out 11 we can use any of this money for the families of ex-oonvicts who have deserted, but at present we shall have to exclude them from the 118t. Will you send to me immediately any familles who are possibilities as this will mean leaving more money free for your other families.

From the earlier lists submitted, the majority of the proposed candidates had had only jall and workhouse sentences. Hence, an early memorandum of June 5, 1931, to the staff from the caso-work supervisor attempted to set up some further basis for selection of a small group of families: "First of all, consider ex-convicts only those who have served sentences in penttentiary and are now released. This does not include fall or workhouse sentences." The following specifio Information was requested: (1) Names of families, number of dependents and ages; (2) whether they are chronic Family Service Organization families or whether 
unemployment following the release from the institution is the major problem; (3) where the sentenoe was served, and date of release, if known; (4) whether relief is being given the family at the present time and the amount; (5) name of v181tor.

The first two ex-convict clients to receive part of the special fund were, loglcally enough, sent to the Ageney by Mr. Roser, treasurer of the Fund, and by a community person, Interested in Mr. Grover Sales' letter explaining the Fund and 1ts location, in the point-of-view column of the local paper, May 27, 1931. The former elient, a family man, was given one rent order from the Lotta Pund, while other relief needs were met from the Agency's general fund for a short contact of one month's duration. He had been paroled from a federal prison the previous September on a charge of "Conspiracy and Violation of Prohibition Act", with no other penal record. He wa unemployed, and in need of Iinanoial assistance. Interestingly enough, this same client was again aseisted in 1935 with speolal needs of clothing, dishes, utensils, and bedding for the family (again in conneotion with general funds) prior to his going on a public made-work program, where his income would prohiblt flling such needs. No other imprisonment had 
Intervened from the period of first closing of contact to the beginning of the next on $10 / 19 / 34$.

The second ex-convict referred by the community person and the client's former emplojer, had been out of prison for one year, after having served three jears and five months at a state penitentlary for embezzlement. A single man, living with his mother, he was given a small amount of assistance with food and with Y.M.C.A. membership, pending his recelving emplojment.

A precedent was immediately set in reporting to the treasurer the families selected, use made of the fund, and aotual expenditures, on a monthly basis. Th1s procedure has remained constant throughout the fifteen year period of the use of the Fund, with amplifications as caseworkers became surer of what they themselves were doing. A congratulatory letter from the treasurer followed the f1rst reports, and thereby flxed the trend for all future reporting. Agency reports are periodically sent by Mr. Roser to the trustees in Boston.

In looking back over the hlstory of the Agency's use of the Lotta Fund and the selection of cases, there appear to be three phases of handling and assimilating the new service-all predetermined to a large extent by the prevalling economic and soclal temper of the perlod. Roughly, 
these perlods seem to subdivide themselves into those of the econom10 "depression" Jears of 1931 and 1932; of the years of economic resurgence, accompanied by the Agency's continual redefining of 1 ts function and more selfconsolous adaptation and increase of sk1lls, beginning in the early $30^{\prime}$ s and extending to, roughly, 1939; the 1inal years of 1940-1946, when defense industries and the problems of war changed the economic setting and inevitably altered concepts of rellef-giving and service. Briefly, these perlods will be sketched as they have bearing only on the use of the Ex-Convict Fund, and no attempt will be made to give a full historical pleture of each period. Unless otherwise epec1fled, the use of the term "total number of ex-conviots" in each of the following three perlods, 1931-1932, 1935-1939, 1940-1946, refers to the total number of the period discussed, and not to the total number of 92 cases carried over the entire flfteen year period 1931-1946. Reference to table 1, page 2l, will show that the Lotta Fund was overdrawn in Louigville during 1933 and 1934, so that the fifteen year review excludes that perlod, except for some correspondence between the Ageney and the treasurer of the Fund. 
TABLE I

NUMBER OF EX CONVICTS ASSISTED BY YEAR, AS COMPARED TO TOTAL CASELOAD BY YEAR, WITH EXPENDITURE, INCOME AND YEARLY BALANCE OF LOTTA FUND

\begin{tabular}{|c|c|c|c|c|c|}
\hline $\begin{array}{r}\text { Year } \\
\text { (1) } \\
\end{array}$ & $\begin{array}{l}\text { Total Agency Case- } \\
\text { load recelving } \\
\text { Service and Relief } \\
(2)\end{array}$ & $\begin{array}{l}\text { No Ex-Con- } \\
\text { victs Ass18- } \\
\text { ted } \\
\text { (3) }\end{array}$ & $\begin{array}{l}\text { Total Agency } \\
\text { expend1 ture } \\
\text { from Lot to Fund } \\
(4) \\
\end{array}$ & $\begin{array}{l}\text { Agency In- } \\
\text { come from } \\
\text { Lotta Fund } \\
(5)\end{array}$ & $\begin{array}{l}\text { Balance of Lot- } \\
\text { ta Fund at end } \\
\text { of year } \\
(6)\end{array}$ \\
\hline $\begin{array}{l}1931 \\
1932 \\
1933 \\
1934 \\
1935 \\
1936 \\
1937 \\
1938 \\
1939 \\
1940 \\
1941 \\
1942 \\
1943 \\
1944 \\
1945 \\
1946\end{array}$ & $\begin{array}{c}4319^{a} \\
4392^{a} \\
2455^{a} \\
2044^{a} \\
1800^{a} \\
1211^{a} \\
801^{b} \\
868 \\
1619 \\
1561 \\
1410 \\
2363^{c} \\
2516 \\
2591 \\
2058 \\
1377\end{array}$ & $\begin{array}{r}13 \\
20 \\
- \\
\overline{8} \\
13 \\
4 \\
18 \\
12 \\
10 \\
5 \\
6 \\
4 \\
4 \\
4 \\
14\end{array}$ & $\begin{array}{c}850.16 \\
1821.69 \\
- \\
162.83 \\
288.46 \\
174.11 \\
945.14 \\
464.18 \\
281.27 \\
167.35 \\
230.67 \\
160.60 \\
198.69 \\
200.44 \\
1,051.46\end{array}$ & $\begin{array}{r}\$ 570.45 \\
893.51 \\
300.00 \\
800.00 \\
600.00 \\
100.00 \\
400.00 \\
800.00 \\
400.00 \\
101.13 \\
300.00 \\
500.00 \\
- \\
500.00 \\
1,000.00\end{array}$ & $\begin{array}{c}- \\
\overline{-} \\
\overline{-} \\
\$ 329.28 \\
140.82 \\
393.71 \\
248.57 \\
184.39 \\
4.25 \\
136.90 \\
406.23 \\
245.63 \\
46.94 \\
346.50 \\
295.04\end{array}$ \\
\hline
\end{tabular}

sibility in the community.

borop in caseload reflects increased referrals to public agency and withdrawal of tax subsidy.

CIncrease in caseload reflects agency's assumption of war-time activities; draft-board reviews, etc., and incluelon of short-term cases in total count. 
Depression Years and Use of Ex-Convict Fund (1931-1932)

Table 1 (page 21) shows that at no other consecutive two-year period were there as many recipients of the Lotta Fund as in 1931 and 1932, although the years of 1938 and 1939 approximate the number. A total of 13 ex-conviots and the1r Pamilies were as81sted during 1931 and 20 in 1932, with a total expenditure, for the two years, of \$267.85. For the only two comparable years 1938-1939--insofar as total numbers of ex-convicts are concerned-a total of $\$ 1409.32$ was spent--only $\$ 246.79$ more than half the amount spent in 1931 and 1932. Since the above figures of 13 for 1931 and 33 for 1932 represent totals in years and not the undupl1cated count, the figures overlap to some extent. Nine cllents recelved assistance during both years; five were assisted only in 1931 , and ten were assisted only in 1932. The unduplicated total recelving assistance for the twe zear period 18 therefore 24.

A clue to the approach used by caseworkers of that period with the ex-convict is immediately shom in the selection of client or clients in the family for direction of treatment. In 11 of the 24 cases the major contactthat 18 the actual preponderance of interviews-was had with the family as a unt, that is, with both man and wife 
and other members of the family. In $108 \mathrm{~s}$ than half the total number of cases of this period was the casework directed toward the ex-convict, himself, as the ollent, and in two of the cases, the ex-convict was a shadowy Iigure, In and out of the family between long periods of desertion. In these two cases relief was directly handled with the wife, and the Ex-Convict Fund woren into the general rellef plan, under the general fund of the Agency.

In going over the total number of cases, one 18 Instantly stmack with the fact that the Fund came as a welcome addition to a tight relief budget, continually threatened with termination, due to the Agency's straitened circumstances. Since the time of beginning and ending of the use of the Fund is not clearly dram in the running record or posted on the rellef sheots, it 18 impossible to see the total rellef plan very clearly; however, in 13 of the 24 cases it is definitely seen that the Ex-Convict Fund was used together with the Agency's general fund--sometimes to supplement a maintenance item, sometimes to carry the famliy over a period of low relief, sometimes to grant a special 1 tem felt to be out of keeping with the necessarily meager "maintenance rellef"--1.e., special Christmas assistance for toys, etc. Although there is evidence throughout these records that the money was graterully used to tide over a 
plan of assistance momentarily ready to fold up, the caseworkers generally did not explain the injeotion of the nev source of funds to the clients. The problem of the hour was unemployment and stark need. It is to be expected that the needs of the ex-convict himself rould be submerged to the most flagrant want of the times. Slightly humerous, as well as sympathy-arousing, is the 11 ustration of the caseworker's frantic search for a penal record in one of her maintenance families and coming up with an old sentence of the client's of 410 days in 1916 for chicken stealing. In this situation the caseworker gave the cllent some interpretation of the use of the Ex-Convict Fund, since the family had previously been told assistance would have to end. She registers, quite erankly, the family's surprise: "They pretended to be considerably amused at the rather unusual source through which the assigtance had come to them."

In the group where apparently assistance came entirely from the Ex-Convict Fund--although among this group this faot is actually not clearly evident in all the cases-the Fund was largely used to supplement the wage-earners' odd jobs. Once it was used for transportation to a legal residence and once 1 was used to furnish teeth to an ex-convict with stomach trouble. 
By far the majority of the cases of this period vere not referred to the Agency as ex-conv10ts, but already were being cared for, together with their families. Most of the ex-convicts were family men--in only a fow instances were they unattached, transient individuals. Desplte the pressures of the period and the great emphasis on unemployment problems, there was, however, a beginning recognition of certain Iimltations in a cllent's eligibllity for the Ex-Convict Fund and of services adapted to some of the problems of the discharged convict. All but $81 x$ of the group of 24 ex-convicts had had prison sentences no farther back than approxlmately one jear. There was, apparently, some feeling that the Fund should be used, as nearly as possible, for those men who were more recently discharged from prisons.

The eix cases in which the men had older prison records illustrate both the above mentioned problem of tapping all resources to 1111 gaps in the Agency rellef budget, as well as a kind of experimentation in testing out the new service. One of the $81 x$ cases is an example of the latter. The client himbelf had heard of the Lotta Fund lorigin unknow), and requested dental care. This service was met by the Agency after verification of the imprisonment period of June 4, 1925-February 23, 1926-1ive years beforefor "Violation of the White Slavery Act". 
Other prison records--besides the one mentioned above and the c1ted case with the record of ohicken stealing--were equally remote from the client's current 11fe: one, ending In 1914 for "False Swearing"; one ending in 1928 for Grand Larceny; another ending in 1925 for Malicious Shooting, as part of a rural feud; lastly, one ending in 1925 for army desertion. In one case, hoverer, there was a series of arrests and imprisonments in jall or workhouse, all of which in a sense brought the problem of the client's poor adjustment to society into greater focus.

Accuracy also marked the early casea. Twenty-three of the 24 cases contained verifications of the incarceration. Verification of the imprisonment of the ollent in the remainIng case, however, was done several years later in a subsequent contact. In most instances veriflcation was done by direct correspondence with the penal institution; sometimes by checking local court house records; by examination of papers in the family's possession; by newspaper clippings. A comparison with statistics on the total percentage of verifications on all the 92 cases may be of interest (See table 7, page 70).

In summing up the general approach of this perlod, one sees the Fund primarily used as a weloome resource for additional rellef for clients who would normally have been 
aseisted by the Agency because of economic need and family problems. Only five of the clients were referred or came to the Ageney because of knowledge of the Lotta Fund. Fet the caseworkers made sure of technical grounds for use of the Fund by verifications of prison records. Also, in slightly more than one fourth of the total number of ex-convict cases there 18 real evidence of the caseworker's conscious attempts directly to deal with some phase of the client's problems of readjustment to the community as a result of his prison record: Efforts were made to have oltizenship rights restored; to have the client reinstated in a lodge where he had lost membership because of his misuse of 1 ts funds; to assiat the client in building up constructive contacts with h1s church; to locate employers unprejudiced to ex-convicts; to return an ex-convict to his legal res1dence where his family might stand by him and where employment prospects might be better for him than elsewhere.

Beginning of Clearer Definition of Service To Bx-Convicts Part of the learning process for the Agency's staff in assimilating the new source of funds and using skills with a slightly different emphasis was the ineritable one of 1 ts limitations. After alightly more than a year of its existence, the Ex-Convict Fund was overdrawn, and the cases 
under care at the time were continued under the general fund of the Agency. A letter, dated May 8, 1934, from the Executive Secretary to the treasurer, sums up the financial status of that period:

You will 11nd in your flles a letter from Miss Fike [Case Work Supervisor] dated August 18, 1932, wh1ch includes a detalled report of the last expenditures of this fund for individual families, At that time the balance due the organ1zation was $\$ 1207.89$. Because we had already overdrawn this amount, we feel that we could not draw further upon future funds until this defic1t had been made up.:

The summary of the income and expenditures 18 as follows: From July, 1931, through July, 1932, we spent \$2671.85; from July, 1931, through July, 1932, we recelved an income from this fund of $\$ 1463.96$, leaving a balance, as given you in the letter of August, 1932, of \$1207.89. On March 17, 1932, we recelved a check for $\$ 300.00$, which reduced the defic1t to $\$ 907.89$. On February 24, 1934, we recelved another check for $\$ 450.00$, leaving a balance due us of $\$ 457.89$.

Of course, we want to make it clear that no ex-convicts who apply for assistance and are in need are refused assistance, but are taken care of out of our general fund or by the Municipal Relief Bureau (10cal public taxsupported agency), according to whichever ageney the case would come in under. When the rest of this deficit is taken care of we can again take care of the special needs of ex-convicts from the Ex-Convict Fund.

Therefore, technically, there were no new ex-convict cases during 1933 and 1934, and from the point of view of Agency mechanics, no cases counted as ex-convict case during this period. Late in 1935 the service was officially resumed. On December 13, 1934, the Agency recelved $\$ 350.00$ from the Fund, leaving a balance on the over-expend1tures 
of \$107.89. On August 1, 1935, another check for $\$ 300,00$ was recelved, leaving a balance of $\$ 192.11$ to be spent for ex-conv1cts. In August, 1935, the staff was again requested to cull from their case-loads a group of ex-convicts who might qualify for financial assistance from the Fund. There is eridence that the selection was thoughtfully done, in view of the I1mited amount of money arailable. Five families were selected in August and three additional families were chosen for December. Although it was inevitable that again these were primarily families already recelving assistance, and the Ex-Convict Fund acted as a supplement, caseworkers now began to inform the cllent more generally of the new source of assistance, and in some instances it was used to cover such special needs as Christmas help, a new suit of clothes, etc., as a boost to the client's morale. Again, a certain trend is observable by examination of the next group of cases, and the perlod seems to have a certain character. Roughly, it falls between the years 1935 and 1940, through 1939. Al though there 18 some overlapping in the total number of cases in this period with the early perlod described above, and with the perlod extending beyond 1939, only one ex-convict had received assistance also in 1931, and four were assisted during the later period, although the major contact was had with these clients during 
1935-1939. In the Agency's history the latter perlod was characterized by gradual crystallization of 1 ts function of primarily meeting service needs, with the major relief responsibility falling to the local public agenc1es. The Munfcipal Rellef Bureau had come into existence in 1929, and by 1937 was one of the outstanding public agencies in the whole country, although later ohange in personnel and shortages of funds created a community problem which inevitably affected the private agency. In 1938 Family Service Organization completed 1ts transfer of cases, where the primary need was an economic one, to the Municipal Bureav of Sociel Service. A newspaper article of the period states: "Family Service Organization will return to its original purpose of social service to the family together with such incidental rellef as such work may require." The W.P.A. program became a resource for the unemployed, and the edge was gradually being taken off the acuteness of the needs of the early thirties.

With this background the Agency was generally in better position to increase its casework skills, to deepen 1ts quality of work, and to extend 1 ts actirities into outpost services. Thirty-five ex-convicts were assisted from 1935 through 1939. A glance at table 1, page 21, shown no danger of threatened deficit of the Ex-Convict 
31

Fund, although a temporary suspension occurred in late 1939 , due to a delayed check. Memoranda from the Executive Secretary to the saff and caseworkers' brief monthly summations of the cases carried indicate greater oelectivity in casefinding and improvement in regular reporting from the caseworkers, although often the actual rehab1l1tative function of the Bund 1a not clearly stated in these reports. A letter from the Execut1ve Secretary to the Treasurer, on March 10 , 1937, points to greater assurance in sesing the ex-convict group as one requiring some special distinction from other fam111es:

We have used the Fund only for those ex-convict familles where we felt that there was some partioular value in having the man have these special funds. Otherwise, the ex-convict families are cared for out of our general relief funde. On the other hand, any unattached exconvicts who have come to us for assistance have been taken care of entirely out of the $\mathrm{Ex}$-Convict Fund. This was particularly true of __, who, you w111 remember, 18 a young, unattached man.

Here emerges a focus on the ex-convict as an individual. Also, a year earlier, another letter in the flles, in response to an out of town ex-convict's point-of-vier letter in the local paper, requesting assistance, explains that the Ex-Convict Fund 18 "primarily for ex-convicts in Loulsville." Actual legal residence was not required, as in other cases needing financial assistance, but the individual in absentie was, reasonably enough, Ineligible for relief, but rather 
directed to his local sources of assistance. Further clariflcation of the service appears, too, in a statement from a report of December, 1938: "We are trying to help particularly those ex-convicts who are walting W.P.A. assignments or who have some opportunity in industry as we feel that it is Important that they do not get too discouraged and revert to stealing or forgery in order to take care of themselves." Here is expressed concern for the individual ex-convict and the temptation facing him to revert to asocial behavior. This preventive aspect of the service is borne out in the study of the actual cases, where employment was felt so Important as a rehabilitative measure and a deterrent to future trouble that wage-rellef was sometimes paid with the Ex-Convict Fund. (For a brief period the Agency maintained a small work-shop as a made-work program.) Caseworkers became more sensitive to the perils of discouragement. Experimentation, also, became part of the feeling-out process in integrating a service, which had more or less been an appendage in the earlier. years, in to the whole range of Agency services. Ex-Convict funds were used for "exploration" perlods to learn more about the client's background and potentialities for being helped. Some confusions in differentiating between ex-convicts and other olients and between the purposes of the two sources of rellef were to be 
expected. Greater flexibility in acceptance of ex-convicts for financial assistance as compared with other olients was evident. In one instance, articulated more clearly than in others similarly handled, the caseworker records that, following a conference with the Executive Secretary on $3 / 3 / 36$, It was decided to use the Fund for the case in question "for experimental purposes" only--that the Agency was not justifled In using its general fund for assistance to the cllent, because of his rery poor background.

Although, in general, clients rere informed of the source of rellef, here, too, there was some difference of opinion. The interesting viewpoint was brought out in connection with one case that: "I do not think it is a good thing to tell the man about the fund as it does put a premium on a penitentiary record. In many instances we have not let the man know the source of the fund and the purpose of 1t." At times bewlldering, too, to caseworker and client, must have been the oocasional instances of supplementation of H.P.A. wages, since clients who were not ex-convicts were continually being told of the inter-agency policy of nonsupplementation of W.P.A. income. Was it a sense of over protection of the ex-convict on the part of the caseworker, who feared the consequences of sub-marginal income on an Individual already in confliot with socioty? Was it merely 
a welcome use of another resource for a few cases among many that the caseworker I1kewse would have been eager to assist? It is 1mpossible to know just what was felt during this period-perhaps something of both feelings.

In a general review of the cases of this period, several facts are noted: The yearly numbers of ex-convicts assisted shows a range of four to 18 per year. The former low number was attributable to the famous 1937 flood, during whioh period Agency activities per se were suspended for a while and clients were assisted by the American Red Cross. The eight ex-convicts assisted in 1935 represent a low count as the service was resumed so late in the year. Of the total number of 35 cases carried from 1935 through 1939, the major1ty, 25, were st1ll men residing w1th their families and in 16 of these cases contacts were held equally with the ex-convict and other members of the fam1ly. In 9 of the total group, the caseworker had primary contact with the ex-convict himself. In the group of 10 unattached individuals, the caserorker, of course, had the major contact with the exconvict himself. Thus, numerically, more than half the number of cases represent major conoern with the ex-convict's prison experiences and feelinge about his readjustment to soclety than in the earlier perlod. In all but 4 cases, the fact of imprisonment was verified, with sometimes not all the 
dates or other data complete, and w1th sometimes excellent information from the penal institutions. Among the four cases in which imprisonment was not actualiy verified, there was evidence in three cases that the man was probably an ex-convict, by mention of a prison record by the referral source. One of the cases, for instance, had been referred to the Agenoy by Mr. Roser, Treasurer of the Lotta Fund. The offense in this situation was an old one-having ended in 1930--and the client stated" of himself that he had "bummed around since 1930". In all but six of the cases, the 1mprisonments were of relatively recent date--all within a year of slightly more from the date of acceptance. One of these six cases, however, had been assisted in 1931 from the ExConvict Iund, and was selected again in 1935 when assistance from the Fund was first resumed.

Although, again, information as to the use of both general and Ex-Conviot Fund is not always clearly brought out in the case-records, in 19 of the 35 cases the financial plan seemed to be a combination of general and special funds, with the latter supplying "special" needs, such as olothing 1tems, seeds for gardening, false teeth, etc. In as many as 16 cases, rellef was drawn entirely from the Ex-Convict Fund, indicating a much more conscious use of the Fund for specifio cllents. 
Wider community knowledge of the existence of the Fund 1s evident, since 11 of the 35 cases came to the Agency as direct referrals from other individuals or agencies for assistance from the Fund, or came at the suggestion of Ind1viduals or agencies who kne $w$ of the Fund's purpose.

In recapitulating th1s period, 1935-1939, one sees perhaps confusion in using the flexible criteriam-not yet written in any definite statement-to accept ex-convicts for assistance from the Lotta Fund. At the same time there appears to be a natural growth toward individualizing the ex-convict clients and consclentlously trying to use the funds for rehabilitative purposes.

\section{Service Related To The Individual} $1940-1946$

An Interesting "proflle" 1s drawn from the years 1940-1946, on table 1, page 2l. The beginning and the endIng year of this period show a relatively high number of exconvicts assisted, while the intervening years of 1941, $1942,1943,1944$, and 1945 represent a marked decrease in the yearly numbers assisted with the Lotta Fund. The arerage for these five years is only 4.6. The drop in numbers of applicants for assistance coincides with the rise in employment opportunit1es. War industries drained the labor market, and even many individuals who by reason of phjsical handicaps, 
poor work-records, evidences of general instability, etc. could not find work in other years, were now pltting into some form of employment. W1 th the war's ending, and the attendant problems of readjustment, skill and experience again became oriteria for adequate employment. One might safely predict that ex-convict requests for assistance will elther remain at the present level, or increase, and that the period for review of the fifteen years of service to ex-conviets is both timely and necessary as preparation for Increased demands and usable criteria to meet these.

In Agency history, the period is marked by refinement of casework skills both in direct treatment of olients and In interpretation of the Agency's work to the community. In 1946 the Agency completed a project which otands as the epitome of 1 ts struggle for high standards of staff development and case-work service-the comprehensive manual of all job classifications in the Agency, and of personnel practices. What has been the derelopment and change in the one small corner of the Agency's varied services of this period-the handling of the ex-convict group? (A comparison of totals by year of ex-convict cases with totals by year of all cases, as show on table 1 , page 21 , Indicates the small part they are of the total case-load). Apparently, the service was afected rather more indirectly than directly 
by the general changes of the perlod. With rapid staff turnover, many osseworkers were no longer close to the struggles of the early derelopmental perlod. Consequently, many of the workers had forgotten or had never absorbed the purpose or mechan1es of the Lotta Fund. On $8 / 17 / 46$, after evidence of the staff's general lack of knowledge of the service became apparent in inadequate reports of their ex-oonvict cases, a memorandum was sent to the staff by the Executive Secretary repeating and enlarging upon faots needed for the reports:

In order to be sure that we have the money in the fund and in order that the workers understand the procedure, any client who is accepted for rellef from the Ex-Convict Fund must be oleared with me first by the worker. If we have sufficient money in the fund, the case can be accepted. At that point the worker is to send me a very brier memo, giving me a statement as to the reason the man was committed, the date and length he was committed, when he was paroled or released, and what the present Bituation 18. There should be a brief statement of his needs and what we hope to do for him and some indication as to the length of time and the amount of rellef. Following the original statement, a memo should be sent to me at the end of each month (not later than the 6th of the following month). Th1s statement should include briefly a report of what has been done, such as the kind of relief and what the plan has been in relation to the relief and what you antlcipate do1ng. The bookkeeper gives me the itemized statement of the relief, so 1t is not necessary for the worker to give me th1s, but the worker should give me the rellef plan and some estimate of the amount needed for the coming month. It is important that the workerg give a brief statement and a clear statement that will be understandable to the secretary and Treasurer. 
How did the service 1 tself grow and change in this period of 1940-1946? Thirty-e1ght ex-convict cases were assisted in this perlod, with four of these overlapping from the previous period. One of these had continued from 19391940, and three were reopened in 1940. In 30 cases--by far the majority--the major contact was with the ex-convict himself. In six cases the approach was directed to the family as a unit. In two cases, interestingly enough, the major contact was definitely with the wife of the ex-convict. In one situation this was purposerully done, apparentiy, since the wlfe had been the client of the Agency's for a period of years during her previous marriage. Ex-Convict funds were used to supplement the family's Aid to Dependent Children's grant. In the other situation, the caseworker apparentiy had unwittingly falien in with the ex-convict's plan of evading contact and securing assistance by sending in his pregnant wife. Later, the oaseworker apparently became aware of what was haning and requested contact with the ex-convict himself.

of the total number of 38 cases of this perlod, 24 were definitely unattached individuals--either single, separated, divorced or wldowed. Twelve were "family men", with one of these having an established home with his mother. Two were women ex-convicts with an established home with 
thelr adolescent sons. A larger number of transient ind1viduals appear in the group than at any other perlod.

As for the rellef plan--all but one ex-conviot were assisted entirely from the Lotta Fund, although the family of one of these was later assisted out of the general fund after the man deserted. In the one case where a combination of funds was used, an interesting distinction was made: a requested grant for repalr of a truck was decided in conference with the Executive Secretary to be so questionable In view of the client's extremely poor background, that the request was met out of general rather than the special fund. This 1s, in a sense, a reversal of an earlier opinion that a questionable request could not be met from the Agency's general fund, but rather, experimentally, from the Lotta Fund.

There were 17 direct and clear-cut referrals from other agencies of individuals for assistance from the Fund. Two additional cases were referred by the penitentiaries, upon release of the clients, for service in locating employment. Eventually they recelved some assistance from the Fund. In two or three additional cases one suspeots the individuals had heard of the existence of the Fund while they were still in prison or while they were wandering about the country. 
All but four of the ex-convicts' penal records were verifled--al though, again, methods and success in securing definite data rary. The penal reoords of two of the cllents could not be verified at all, al though attempts were made, and in two situations the caseworker made no attemt at verification.

Three ex-convicts had only jall or workhouse sentences. Two clients, assisted previously, were assisted again, although their prison terms were now as far back as three years prior to the last contact. One client had a penal record of about s1x years prior to acceptance for assistance from the Fund, al though jail and workhouse sentences had intervened. Not counting the ollents whose terms could not be adequately verifled, 27 ex-convicts had penal record not much farther back than one year from the date of acceptance.

There are some interesting variants in types of services apparent in this period, many of which are, in a sense, precedent-setting, and serve as material from which policy emerges. One case was accepted to help the client establish a work-record by part-payment of sheltered workshop wages from the Nund. It 18 brought out more clearly than in the past, and so stated in case-records, that temporary help may act as a preventive against temptation-a sort of Immediate brake on rec1div18m. Also, the question 
of residence seems falrly definite now in several statements as result of conference with the Executive Secretary. One record carries the statement: "The Ex-Convict Fund is not restricted to residents." Interesting, too, 1s the group of cases containing recording to the effect that oriteria for treatability be much more flexibly applied to ex-convicts than to other clients. One statement is very nicely put:

--.-The Ex-Convict Fund was donated by a woman interested in helping even those who do not show possibilities for rehabilitation. It would be posalble, therefore, to use $1 \mathrm{t}$ for the repalr of Mr. A's artificlal imb and for temporary maintenance. Then we could refer the case to Jefferson county Welfare Department.

Following along this line, there appears a trend to give rellef for short periods, and if chronicity of the problem is in evidence, to refer the client to a public agency for long-term assistance.

Emplrically, therefore, we see in actual practice precedent-setting opinions. As the study procedes, these will become clear as the picture emerges of who the ex-convict really 18, what the total practice in reller-giving has been, and what the practice appears to be in other agenc1es. It is suggested that the above data be compared with later tables giving a total ploture of the ex-convict's social status to bring out differences in the three periods cited. 
CHAPTER II

PRACTICE IN OTHER AGENCIES PARTICIPATING IN USE OF FUND

In connection with the present study, the names and locations of the seven agencies--other than Family Service Organization--sharing in the 1ncome from the Lotta Fund for Alding D1scharged Convicts-were secured from the trustees In February, 1947. These agencies are: (I) Massachusetts Soclety for Alding Discharged Prisoners, Boston, Hassachusetts; (2) Prison Association of California, San Jose, California; (3) St. Louls Committee for Alaing Disoharged Prisoners, St. Louis, Missour1; (4) Centrel Howard Assoc1ation, Chioago, Illinois; (4) Prison Association of New York, New York, New York; (6) Prisoners Relief Soclety, Washington, D. C.; (7) Volunteer Prisoners' Ald Soclety, New Orleans, Loulsiana. Upon recelpt of the names of the agencies a letter was written executives of these agencles, requesting certain kind of information that might be of interest in comparing with our findings. Some information regarding the agency 1tself was requested - its function, origin of funds other than the Lotta Fund, 1ts personnel and the allocating of cases elther to one certain worker or to all 
workers. General information about the cases was felt desirable: the approximate average number of ex-convicts handled yearly, as well as the total number handled; general information regarding the sex, residence, family attachments of the ex-convicts. Some general points regarding the handling of rellef for the ex-convicts were requested: whether this was relief for maintenance or for special 1tems; whether 1t was primarily in cash. Additional data regarding the dpproximate average duration of ex-convict contacts, method of reporting to the trustees, an est1mate of total sucoess in dealing with the ex-convict group, was solicited. It seemed well to know $1 f$ any study of any of the seven agencies' work with exconviots assisted with the Lotta Fund had ever been made. As with many similar inquiries, the success in getting responses was limited. Only three agencies sent any kind of reply; The Prisoners Relief Society of Washington, D. C.; The Prison Association of New York; The John Howard Assoo1ation of Chicago, Ill. In general, it 18 difficult to glean from the material sent, answers to specific questions, but some interesting information was obtained. From enclosures, which were chlefly coples of the charter of incorporation, correspondence with government officlals, and news paper cl1ppings, one gathers that Dr. Dudding, a 
much venerated man of past 85 jears, 1s president of the Board of Direotors of The Prisoners Rellef Soclety of Washington, and that one of the organlzation's chlef alms is in "managing large institutions and 18 authority on the proper conduct of hospitals and state and government institutions". The organization was "lounded in Huntington in 1914" and "has been financed without a single drive for funds or without a solicltor". The charter's stated purpose of the agency 18:

"To sol1c1t, accept and recelve money, funds, endowments, and contributions of every kind and description, to be used in the social and moral uplift of ex-convicts and to render them financial ald and assistance, to secure homes and employment for exconvicts, to render financial ald and assistance to the families of men serving terms in prison, and to do all things that will better the condition of exconvicts, the1r families and the families of men serving prison terms, and for all other purposea necessary or incidental to the proper conducts of sald work and business, and to engage in all kinds of charltable and philantropic work."

The Corporation office is located in Vashington, D. C., and a branch offlce 18 retained in Huntington, $W . \mathrm{Va}$. Apparentiy, no distinction 18 made in the source of funds for any special purpose, since the total program of the agency is directed toward prison work: "Whenever we recelve funds from any source left by will to ald ex-convicts we use it to ald worthy cases and no part of the fund 18 used for salaries." No information as to personnel was 
secured other than the statement: "The by-laws of the Soclety provides that no person employed by the Corporation can or shall recelve more than $\$ 100.00$ a month room and board." Another interesting statement of recent focus (February 12, 1947) in that agency 18:

"It was through the efforts of the Prisoners Relief Soclety that convicts and ex-convicts were permitted to enl 18t and be drafted into the armed forces during the War. They made good soldiers too and gave no unusual trouble. Our soclety is not taking on any new cases now as we have all we can do in taking care of the committments."

No additional information wasecured as to total caseload, ete.

The reply Irom The Prison Association of New York stated that pressures of the period, especially with the New York Legislature in session, precluded their giving the desired information. The Agency's annual report for 1945 was forwarded. The letter commented briefly on the Lotta Fund as follows: "We have recelved contributions from the Lotta Crabtree fund and our case records are quite olear on that point". The annual report, however, does not give information as to the source of the Association's funds for financial assistance to ex-conviots, but rather summarizes the broad activities of the organization, as indicated by I1sting of 1ts standing committees: Committee on Law; Committee on Finance; Committee on Detentions; Committee 
on Nominations; Committee on Probation and Parole; Committee on Prison Administration. The Association, founded in 1844 and incorporated in 1846, is imposingly active in championing legislation for prison reform, for handing of juvenile delinquents, for probation improvement, eto. The Assooiation was "consplcuously identified with the writing and passage of the first probation law in this State orer forty years ago."I In short, the total function of the association is "to assist in the flelds of crime prevention and in the improvement of those methods of orime treatment relating to court procedures, institutional administration and planning, parole and postrelease activities." $2 A_{B}$ part of 1 ts total function, the Association malntalns an Employment and Relief Bureau, "under the able guidance and direction of Mr. Harry Sohwartz who is credited with more than thirty-five years experience in the field of crime treatment, prevention, and aroldance" 3 , and a Family Service Bureau, "under the

IState on New York, The One Fundred and First Annugl Report of the Prison Association of Nen York, Legislative Dooument (1946) No. 29 (Albany: W11liams Press, Inc., 1946) p. 19 .

2Ib1d., p. 25 .

IIb1d. , p. 46. 
supervision and guidance of M1s8 Margaret Murdock. Her experience of many years in dealing with families in circumstances less fortunate than most, well qualifles her for the task of directing the Bureau."I The I1rst service gives temporary lodging, meals, and cash relief to released prisoners, the majority of whom come from N. Y. City and state penal institutions and attempts to find emplojment for them. Total expend1tures for 1945 were $\$ 2,281.10$ and 808 men were interviewed. The Family Service Bureau enumerates sereral primary functions:

It meets the urgent need of providing for the family of the prisoner during the period of his incarceration.... removing a primary cause of bitterness and thus indirectig alds in his rehabliltation..... Temporary financial help is given where $1 \mathrm{t}$ is needed. The polloy of the Bureau precludes 1 ts acting as a substitute for public assietance, but $1 t$ can be a rery present help at the beginning when the shock is greatest and help is most needed. It promptly places the families in touch with public rellef authorities and may continue to supply necessary supplementary funds after rellef is obtained.2

Also, the intangibles of case-work treatment are Indicated by the Bureau's services in preparing the family psychologically for the return of the husband; in providing recreational activities for the family, etc. The total number of cases under care carried in this division during

I Ibia., p. 51 .

Inta. , p. 50 . 
1945 was given 28 234, with an expenditure of $\$ 6,828,06$. Statistics only for the two service bureaus I1sted abore, The Emplojment and Rellef Bureau and the Family Service Bureau, were given in the annual report. No additional information as to number and training of personnel was obtalnable.

The John Howard Association of Chicago, Illino1s gave a full outline of 1 ts function, services, and method of financlal assistance, succinctiy summed up as follows, In a letter of Feb, 13, 1947:

The John Howard Association (formerly Central Howard Association) was founded in 1901, to provide assistance to men released from prison, through casework service, employment placement, temporary inancial ald. The agency also fosters crime prevention activities, and the improvement of prisons. It is the only casework agency in Illinois which works exclusively with men in prison and with men released Irom correctional institutions, regardlese of race, creed, or color, to ald them in their rehabilitation to productive ilving and good citizenship.

The Agency is a member of the Council of Soclal Agencies of Chicago, participates in the Community Fund, and is a beneflclary of two foundations. It 18 principally supported through the contributions of individuals interested in our particular work.

Our staff consists of a professionally trained executive secretary two professionaliy trained caseworkers, one research fellow, whose salary is financed through a non-budgetary fund, and two clerical personnel.

The funds recelved from the Lotta Crabtree Fund are very important to us in our employment placement program. 
We work with approximately 500 men a year, both inmates and men released from prisons. The total budget for the year is approximately $\$ 15,000$, exclusive of non-budgetary funds for research, seminars, and scholarship grants.

Financial assistance for the most part 1s on a loan basis, and we recelve about $60 \%$ in return. Prior to the war, $85 \%$ of the men we assisted were successful, al though during the war, the percentage ran considerably higher.

Although the Association had hoped to make a study of the use of the Lotta. Fund in their work, this to date had not been done.

Al though use of the term "men" may be collective for both sexes, no particular mention is made of women prisoners or ex-convicts in any of the three agencies answering inquiries. The three agencies have a broad scope of activities dealing directly with problems of crime prevention, imprisonment, and release. Agsigtance to ex-convicts is a logical part of their entire program, and no doubt special skills in some of the agencles, and long acquaintance, by experience, with practical problems of court procedures, prison life, and parole requirements must create a helpful background in dealing with released prisoners and their familles. While It is not possible to evaluate the effect of the caseworker's general inexperience with these problems on the handing of ex-conviet cases, in a setting like the Family Service Organization, there undoubtedly is some effect, 11 only within the caseworker's own acceptance of what may seem an 
51

alien problem in the gamut of a private family agency's caseload. Although it is impossible to state definitely that the Family Service Organization, set up to render service to an undifferentiated clientele, was the only agency, organized on this basis, selected to administer the Lotta Fund, the titles of all the other agencies suggest functions similar to those of the three Associations described above. 
CHAPTER III

\section{CHARACTERISTICS OF PERSONS AIDED}

It was seen, in Chapter I, that the total Agency experlence 1n handling the ex-convict cases, from 19311946, seemed logically to fall into three perlods, and that the oharacter of the service, general handling of relief, community arareness of existence of the local resource for ex-convicts in these respective perlods closely followed trends in casework thinking, changes in agency function, etc. A glance at Table 1, page 2l, helps put the Agency's service to ex-convicts in somewhat clearer perspective for the total period than might appear in the discussion in Chapter I, where necessary focus on the handling itself emphasizes those cases. Actually, the numbers of ex-convicts assisted each year is exceedingly small as compared to the total numbers of cases carriod each year-a relationship of 20 ex-convict cases to 4392 undifferentiated cases, in the year of greatest assistance to ex-convicts (1932), and a relationshlp of 4 ex-convict cases to 801 undifferentiated cases in the year of least assistance to both ex-convict as well as other cases (1937). 
It is understandable that the service to ex-convicts might have lost 1tself somewhat in the greater pressures and responsibilities of an undifferentiated caseload. Some objeotive review of who the ex-convict really la-what makes him stand out, if really he does, from the rest of the caseload-1s needed better to visualize the service as it exists and to clarify certaln criteria for acceptance and treatment of these indiriduals.

Data From 92 Case-Records

As the name 1mpl1es, "Family Service Organization" has, as its mainspring, the motive of preserving family iffe and preventing 1 ts breakdown. The majorlty of 1 ts clients are part of a bona eide family group. The unattacbed individual represents the exception to this majority and are accepted for casework treatment (that may or may not involve financial help) only after considerable scruting of the indiridual's capacity for taking help, for sharing in the casework process, etc. has been attempted during the initial application. It was evident, in analyzing the period 1940-1946, during whlch time the ex-convict was increasingly seen as an individual without family ties, that definite statements in records appeared, indicating that treatab1lity was not a criterion for acoeptance. As brought out in the 
discussion in Chapter I one of suoh statements bears repeating: "...The ex-convict fund was donated by a woman interested in halping even those who do not show possibilities for rehabilitation", and therefore assistanoe was granted the cllent in question, although his penal record indicated repetitive asocial behavior, his work record was negligible, and he had no family ties. Comments on records read for this study bring out often, as result of conference with caseworker and Agenoy Executive, that the ex-convict need not express a desire for service in order to recelve assistance. Another statement lends weight to this conviction: "He (the client) probably will have to be helped without using the same criteria as we did for giving rellef to most clients. He probably is fearful of intrusion into his personal affairs and I doubt that he is near enough normal to take any help in discussing his feelings about this." This client, whose social situation was scancely known, was requesting assistance pending recelpt of wages on a job. Also, 1t was observed in Chapter I that residence requirements are waived in the case of ex-convicts, and that the only stipulation for receiving the Ex-Convict Fund is that the client must be residing, at the time of application, in Loulovilie. While exceptions are made with regard to residence of all clients, again these exceptions 
are in the minority and predicate real considerations of treatability within the client, especially where a relief request is involved. Exceptions might be the meeting of an emergency for one instance, the granting of assistance where non-residence is a technical matter--1.e., the situation of a Louisville woman's losing residence by virtue of marriage to a non-resident man, as occurred during World War II--and with similar unusual circumstances. Generally, assistance is given only when the client has proven residence of at least one year in the State and $81 x$ months in Jefferson County.

Requirements as to race or religious bellefs do not exist; however, the Jewish Welfare Federation in the community does meet the needs of cllents of Jewish falth. Insofar as relations of thite to Negro population is concerned, official statistics will not be available again until 1950; however, recent estimates, according to the Kentucky Room of the Louisville Free Public Library, show the general population of Louisville, according to the State Board of Health, to be 363,100 , as of July, 1947, whlle the Urban League estimated the Negro population to have been between 50,000 and 51,000 in July, 1946. The percentage of Negro to White population is therefore 14 plus \% (almost 15\%). Within the Agency, the ratio of White to Negro clients 
given financial assistance is four to one. At the end of 1947, service and rellef was given to 1377 families, of which 338 were Negroes.

Since Family Service statistics are not computed on the basls of who the cllent 1s--1.e., whether major contact has been with husband or wife--it is impossible to use general Ilgures that would have any meaning in relation to sex of the ex-conviots treated; however, for the purpose of getting a picture of who the "ex-convict" really is, the visualization of relatire number of men ex-convicts to women in the same category seems important.

Table 2, page 58, gives a pleture of data secured from the 92 case records of the fifteen year period during which the Lotta Fund has been used, in relation to sex, race, religion, residence, family status--1.e., whether the indiridual has family ties or not. In the latter category, a married indiridual, living with his spouse at the time of contact, an individual living in a commonlaw relationship of long standing, an individual living in a family group--1.e., in an established home with Mother or chlldren-all were regarded as "attached". In the opposite group fell those individuals who most obviously have no lamily ties, have el ther been widowed, separated or dirorced from their spouses, or have never married nor 
established a home with any person or persons. In addition to the above data, it was interesting to investigate the place of birth of these individuals. As shown in table 2 , certain facts stand out and give a plcture of the origin of the clients in question.

It 18 immediately outstanding thet in the ex-convict group the overwhelming majority of Individuals who have been offendors are men. This does not mean that the caseworker necessarily considered the ex-convict as the cllent to be treated, within the framework of his ow family setting. Later it will be seen where the caseworker actually put the major emphasis (see table 10, page 81 ). It has already been seen how the trend to treat the ex-convict direotly has consistently grown in the historical development of the service. The above figures do indioate that the person for whose rehabilitation the Lotta Fund was primarily Intended has been in almost all cases a man. For a private family agency this fact may pose at least temporary problems, in that, until recently, most such agencies have been unable to obtain men caseworkers--primarily due to the War and also to salaries incommensurate with obligations and respons1bilitles of mon caseworkers who are heads of households. It may be argued that only the skill of the caseworker has meaning in treatment, and not his or her sex; however, 
TABLE 2

DATA FROM 92 EX_CONVICT CASE_RECORDS, AS TO SEX, RACE, RELIGION, RESIDENCE, FAMILY STATUS, AND BIRTHPLACE

\begin{tabular}{|c|c|c|c|c|c|c|c|c|c|c|c|c|c|c|c|c|c|}
\hline $\begin{array}{l}\text { Total No. } \\
\text { Ex-Convicts }\end{array}$ & $\mathrm{M}^{\mathrm{Se}}$ & & $\begin{array}{l}\text { Rat } \\
h\end{array}$ & & Prot. & Cath. & $\begin{array}{l}\text { e11g10 } \\
\text { other }\end{array}$ & None & Unk. & $\begin{array}{l}\text { Leg } \\
\text { Yes }\end{array}$ & No & Unk. & $\begin{array}{l}\text { Attg } \\
\text { Yes }\end{array}$ & $\begin{array}{l}\text { ched } \\
\text { No }\end{array}$ & $\begin{array}{l}\text { Birt } \\
\mathrm{y} .\end{array}$ & $\begin{array}{l}\text { place } \\
\text { ther }\end{array}$ & Unk. \\
\hline 92 & 89 & 3 & 68 & 24 & 33 & 8 & 1 & 14 & 36 & 67 & 13 & 12 & 55 & 37 & $52^{b}$ & 23 & 17 \\
\hline
\end{tabular}

achristian Scientist

$b_{14}$ of these were born in Loulsville, $K_{y}$. 
certaln practical aspects of treatment, such as need for home-visits in undesirable locations (1.e., flop-houses, houses of prostitution, etc.) could be performed more easily by men than by women caseworkers. Undeniably, also, certain personality problems of unattached men respond better to handling by men than by women caseworkers. Although flgures are not obtalnable, comments on records read and observations of the obvious selection of a man caseworker whenerer possible for ex-convicts accopted by the Family Service Organization point to the desirability of giving considerable thought to the sex of the caseworker in assigning these cases. It has also been seen that there is considerable evidence that the other agencles sharing the Lotta Fund have geared their services more to men than to women.

With regard to race, it appears that, proportionately, there is a higher ratlo of Negro to White cllents than the ratio in undifferentiated cases. It is difficult to assign ang particular meaning to this, as the proportion is not greatly different. Throughout the remalnder of the text, no further differentiation between White and Negro clients is made, as Agency monthly reports no longer separate the two races, insofar as problems seen and services rendered, and the division seems artificial with respect to the 
handling of the Lotta Fund. In most of the following material, also, differentiation between sexes is seldom made, as the division did not lend significance to the study.

The signifleant fact seen with relation to religion is the large number of "Unknoms". Inval1d, too, in most cases, is the data on the different religlous falths, since it was not always brought out how the information was secured. Often the religlous falth appeared on facesheets, or was somewhat inclientally secured. Of most significance to the reader of the cases is the slight emphasis put by caseworkers on the use and meaning of religion to the individual client, and the disregard for even securing this data in so many cases. Outstanding was the mention of the one client's use of Christian Sclence faith in healing, tc. In the one case singled out in the above table.

It is interesting to note that 67 of the 92 exconvicts were legal residents of Loulsville--a higher proportion than one might expect. Bren among the "Unknown" group, in some instances there was indication that the individual had some tles in Loulsville and might even have legal residence in the c1ty, or at least in the State. Further breaking down of the residence flgures 
61

brings out that only 19 of the 92 ex-convicts could be definitely said to be "drifterg" or trangients moving from one community to another. (There were only 2 of these in the perlod 1931-1932; 61x in the period 1939-1940; eleven in the period 1940-1946). Again, the residence figures are subject to some inaccuraoy, as resldence was not alrays verlfied per ge, but soclal-service exchange clearIngs, records from other agencles, work-records, etc. In most cases seemed clearly to establish residence. Greater care was exerted by the caseworker in checking residence than in obtaining data on religion.

Bearing out the evidence that the majority of exconvicts were of local origin, is the fact that 52 of them were born in Kentuoky, 14 of these in Loulsville, the remainder preponderantiy in mural sections of the State (except for possibly three of these men). Twenty-three ex-convicts were born in other states--the majority orlginating in the sister states of Indiana and Tennessee. Lou1siana, Alabama, M1s81s81pp1 and III1no1s were given as other birthplaces.

From the figures, one would deduce the conolusion thet, whlle the transient, unattached group of ex-conviet clients are in the minority, there is a trend toward increase of this group and contingent need to clarify the 
kind of service most sultable to these individuals.

Of interest to the caseworker are clues to the background of the ex-convicts. Because of variations in historytaking, lacts regarding parental tles are not present with enough uniformity to make an objective statiatical record; however, time after time the comment was made on schedules of the case-records that the ex-convict had come from a broken home situation. This fact, though, 1s largely true of many other clients of the Agency who are not exconvicts, but who have had serlous personality difficulties and problems in adjusting to accepted norms of soclety. Within easier reach of statistical study and of value to the caseworker, intent on assessing potentialities of the ex-convict client and finding practical means of rehabilitation with regard to employment and training, are the school and work records of these ex-convicts. Tables 3 and 4, page 63, give some picture of the ex-convict clients' background with respect to education, training, and workrecords. In determining whether the individual is "skilled" or "unskilied", one encounters the obvious drawbacks of unrellability of the clients' statements and lack of complete veriflcations; however, wherever there is considerable question expressed by the caseworker with regard to the client's rellability, the information was 
TABLE 3

EDUCATIONAL RATINGS AND TRAINING OF 92 EX-CONVICTS ASSISTED

VITH LOTTA WUND BY THE FAMILY SERVICE ORGANIZATION

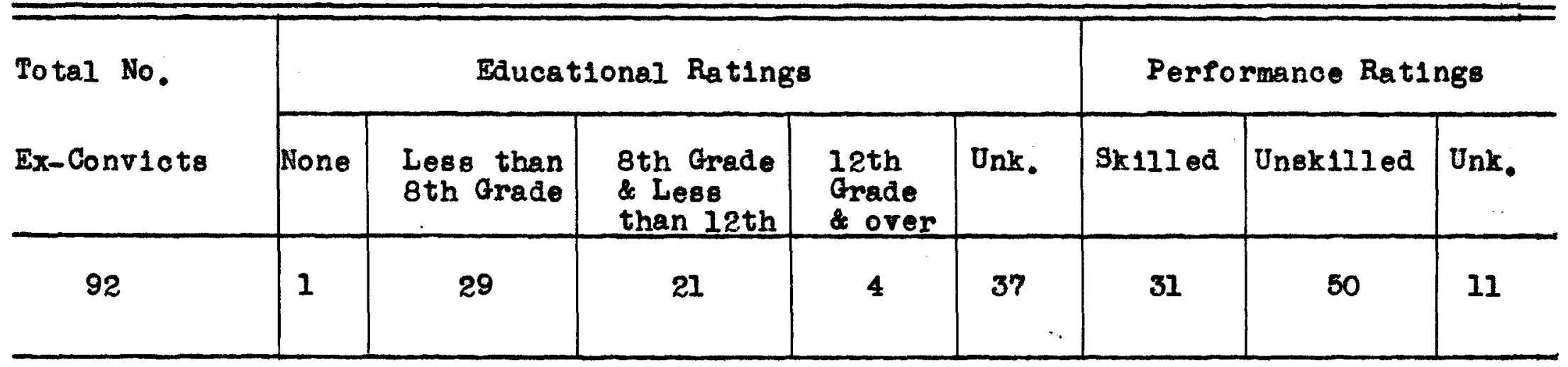

TABLE 4

EMPLOYMENT RECORDS OF 92 EX_CONVICTS ASSISTED WITH LOTTA FUND

BY FAMILY SERVICE ORGANIZATION

\begin{tabular}{c|c|c|c}
\hline \hline $\begin{array}{c}\text { Total No. } \\
\text { Ex-Conviots }\end{array}$ & $\begin{array}{l}\text { Continuous } \\
\text { Work Reoord }\end{array}$ & $\begin{array}{l}\text { Casual, Irregular } \\
\text { Vork Records }\end{array}$ & $\begin{array}{l}\text { Unk. or } \\
\text { Inf. Inval1d }\end{array}$ \\
\hline 92 & 13 & 44 & 35 \\
\hline
\end{tabular}


64

checked "unknown". This form of checking applies also to educational ratings, many of which originate from clients' own statements. Work-records, however, were checked when verified and are classified according to amount of verification done, continuity of jobs held, and length of work-records. If the latter preponderantis fell In sequence of jobs lasting less than one month, the enployment record was classifled as "casuil employment". Tables 3 and 4 give some indioation of the educational level of the ex-convict group, with the greater number of clients falling in the "lesg than 8th" and "8th and less than $12 t h "$ grade ratings, and with again a large proportion of unknown. More than half the number definitoiy fell in the unskilled group. This group represents, largely, those who had elther no work-record or had been employed on unskilled laboring jobs. The skilled workers Inoluded, as examples, Individuals in the more skilled branches of labor-construction workers, mechanics, "white-collar" workers, and a fev professionally skilled Individuals. (Two were miters of acknowledged skill.) Four individuals claimed training in extension classes or In other professional schools--listed are courses in commerclal art, woodrork, poetry, blacksmithing, craftsmanshlp, business. 
Employment records were difficult to rate, as information in case records was often extremely difficult to draw together, rerifioations were incomplete, and interpretation is apt to be somewhat subjectively colored; however, in general, as shown in table 4, 35 individuals gave such meager information, or so l1ttle information was solicited by the caseworker, that the information was rated unknown or invalid. In this group fell the obvious "drifters"; those whose given records could never be checked; those who were sent on jobs but Immediately reported some accident or casualty to prevent their workIng; and those who were supported by their spouses. Of the 57 who had verified records, 44 had very 1 rregular work-records, usually of very short duration. In this group, the majority displayed restlessness in quitting one job after another and generaliy had unsatisfactory ratings by employers, due to arinking or absenteelsm. In this group, too, fell the seasonal workers--carpenters, tobacco workers, domestics, etc.--and those who embarked on their own businesses which were sporadic or unsuccessful. The most stable group of individuals, insofar as employment is concerned, again show only relatively good work records, as compared to the other groupings. Al though each of the 92 case-records were closely perused, with notations made 
as to the sequence of jobs, rate of pay, duration of jobs, reason for discharge, etc. (see schedule, Appendix), Information as to these facts is not consistent in each case record. Often the caseworker took the referral of the case from another agency, and incorporated 1 ts work-record as authentic. There is uneveness in the persistence and quality of checking or verifying work records. The above Iigure of 13 individuals with stable work-records is therefore somewhat tentative. It indicates a group of Individuals who have had at least one or two records of employment of more than two years' duration. Often the imprisonment broke a period of such employment. Often, too, the depression period of the early thirties manifestly interrupted what otherwise appeared to be a stable employment record, and individuals falling in this group were assisted in getting onto made-work programs, where they usually acquired very good ratings, indicating potentlal stability. From the information secured, $\$ 6.00$ was the lowest weekly pay-rate given, for a 17 year-old grocery clerk, and $\$ 60.50$ for a construction employee at a bridge company the highest weekly salary.

How old are these ex-convicts? The age of the Individual has meaning for the caseworker in terms of treatability of the cllent. Table 5 shows the age ranges of the 92 ex-convict cllents assisted by the Agency: 
TABLE 5

AGE RANGES OF 92 EX CONVICT CLIENTS ASSISTED WITH LOTTA FUND BY THE FAMILY SERVICE ORGANIZATION

\begin{tabular}{l|c|c|c}
\hline Age & Total & M & F \\
\hline Total & 92 & 89 & 3 \\
\hline Under 25 & 2 & 2 & 0 \\
\hline 25 Under 35 & 33 & 32 & 2 \\
\hline 35 Under 45 & 34 & 32 & 2 \\
\hline 45 Under 55 & 15 & 15 & 0 \\
\hline 55 snd over & 2 & 2 & 0 \\
\hline Unknorm & 6 & 6 & 0 \\
\hline
\end{tabular}

It is evident, from the above table, that the Agency has assisted more ex-conviot cllents in the age range 25 to 45 than any other age group. It appears, too, that the tendenoy is toward older, rather than younger, clients' reaching the Agency, so that expectation of success of casework treatment might not be as high as with younger group of individuals.

From a caseworker's point of view, there are strong evidences of emotional instabllity of varying degrees evident in the personalities of the ex-convict clients; however, again, instability and immaturity are often seen 
in other cllents who come to the Agency for service with regard to marltal problems, problems of relationship to others, work adjustments, etc. An 1noreasing tendency, over the years, in the handling of ex-convict clients, 18 the greater effort to secure psychiatric consultation or to locate records from other agencies, pertaining to the clients' mental or emotional disturbances. Table 6 below shows the extent of the diagnosed mental 1IIness among the ex-convict group, as well as diagnosed physical 1Ilness or handicap.

\section{TABLE 6}

EXTENT OF DIAGNOSED MENTAL ILLNESS AND PHYSICAL ILLNESS OR HANDICAP ANONG EX-CONVICT CLIENTS

\begin{tabular}{c|c|c}
\hline $\begin{array}{l}\text { Total No. } \\
\text { Ex-Convicts }\end{array}$ & $\begin{array}{l}\text { Diagnosed } \\
\text { Mental } \\
\text { Illness }\end{array}$ & $\begin{array}{l}\text { Diagnosed } \\
\text { Physical Iliness } \\
\text { or Handicap }\end{array}$ \\
\hline 92 & 9 & 26 \\
\hline
\end{tabular}

A relatively small proportion of the ex-convict group have had diagnosed mental 1Ilness; however, this group represents actual psychiatric study with diagnosis of serious mental handicap, while another group were rated "unstable" or as having "simple adult maladjustment", 
and another large group showed, in their contact with the Agency, erratic and Immature behavior, but these borderline groupings are diffioult to classify into objective data. Twenty-six individuals had physical illness or handicaps of serlous effect on their adjustment--1.e., loss of $11 \mathrm{mb}$, partial loss of sight, chronic heart allments, etc. No acute 1linesses were included, such as acute venereal disease, influenza, etc.

\section{Penal Records}

Al though the penal records of each ex-convict client are subject to some inaccuracy in getting full details as to the type of offense, dates of incarceration and veriflcations, on the whole the caseworkers appeared conscientious in securing data that would identify the ollent as an ex-convict, and eligible to receive the Lotta Fund. Gaps in Information, however, do stand out when certaln bas1o questions are asked regarding ver1floations of the penal records and follow-ups in securing information direotly from the prison regarding the cllent's adjustment and potentialities for being helped. Table ?, 70, gives an overall picture of the extent of verifications made of the cllent's stated penal record and of inclusion of material from the prisons or reformatories. Verifications 
show variations in extent of getting detalled information, In timing, etc,, but the schedules of cases read were ohecked affirmitively if even partial information was secured. Also, with regard to inclusion of material from penal institutions about the client, the schedules were checked affirmitively whether the information was solicited by the caseworker, Initialiy sent by the penal institution, or secured via other rellable agency records.

\section{TABLE 7}

EXTENT OF VIRIFICATION OF PENAL RECORDS AND OF INCLUSION OF MATERIAL ABOUT EX-CONVICT FROM PENAL INSTITUTIONS

\begin{tabular}{|c|c|c|c|c|c|c|}
\hline \multirow{2}{*}{$\begin{array}{l}\text { Total No. } \\
\text { Ex-Conviots }\end{array}$} & \multicolumn{3}{|c|}{ Verifications } & \multicolumn{3}{|c|}{ Inciusion of Haterial } \\
\hline & Yes & No & $\begin{array}{l}\text { Unable } \\
\text { to verify }\end{array}$ & Yes & $\begin{array}{l}\text { No or } \\
\text { Material } \\
\text { Inadequate }\end{array}$ & $\begin{array}{l}\text { Unable to } \\
\text { Secure }\end{array}$ \\
\hline 92 & 83 & 6 & 3 & 40 & 49 & 3 \\
\hline
\end{tabular}

The table indicates that only $81 x$ ex-convict records were definitely not verified in any way, and that 83 of them were checked, by a varlety of means to be sure, but with enough information to establish the client as an exconv1ct. The means used ranged from direct correspondence to penal institutions to perusal of parole papers and 
71

accepting the statements of reliable referral sources-1.e., federal and state probation officers or other agenc1es, newspaper articles, etc. Less in evidence in the case records is the inclusion of correspondence, whether a short letter or complete summary, erom the Institution of the client's incarceration. More than half have no material at all, or material with such meager, Inadequate data, as to be of no help at all. The State prisons generally responded very briefly or not at all to the caseworker's inquiries. The Federal prisons generally sent excellent evaluative materlal, including full physical, psychiatric, psychological and social data.

Are these clients recialvists? Only an incomplete and tentative answer can be given, since only the record prior and during the Agency contact can be used. Then, too, one faces the fact that although an Individual may have only one sentence listed for commission of a felony, at the same time he may appear to be a repeater in minor offenses or misdemeanors, such as drunkenness, disorderly conduct, etc. Artificial, too, is the taking for granted that all persons committing only one offense are equally treatable and equally gullty before the law. Too many factors enter into the classification of the crime 
Itself and of the person committing 1t. One offender may have been induced to support his family by a temporary venture into bootlegging; another may have committed murder as a culmination of many other small, but viclous, attacks of violenoe. "A good motive does not prevent an act from being a crime nor does the law punish a bad motive if the behavior is not prohibited. But if the function of the criminal law 18 to protect society by reforming the offender his motive should not only be considered but should play an important role."I For purposes of the present study, however, and for use in a IImited sense, table 8 , page 73 , shows the number of prison sentences per ex-convict client, with accompanying record of jurenile delinquenoy, work-house or jail sentences falling within each category. In checking numbers of sentences, only imprisonment in state or federal prisons or reformatorles were considered, while the accompanying juvenile delinquenoy, misdemeanor record Indicates not the number of such offenses, but the existence of any record other than for felonies.

$1_{\text {Nathaniel }} \mathrm{F}$. Cantor, Crime and Societr (New York: Henry Holt and Co., i939), p. 277, quoting Act. Intent1on and botire in the Criminai Lar, (1917), 26, Yale L. J., 645 . 
TABLE 8

NUMBER OF PRISON SENTENCES PER EX CONVICT CLIENT WITH ACCOMPANYING JUVENILE DELINQUENCY, JAIL OR WORKHOUSE RECORDS

\begin{tabular}{|c|c|c|c|c|c|c|c|c|c|c|}
\hline \multirow[t]{2}{*}{$\begin{array}{l}\text { No. of Prison } \\
\text { Sentences per } \\
\text { Ex-Convict }\end{array}$} & \multicolumn{2}{|c|}{$\begin{array}{l}\text { No of } \\
\text { Ex-Convicts }\end{array}$} & \multirow[t]{2}{*}{$\begin{array}{l}\text { Total No } \\
E_{x-C o n v 10 t s}\end{array}$} & \multirow[t]{2}{*}{$\begin{array}{l}\text { Total No. } \\
\text { Offenses } \\
\text { Committed }\end{array}$} & \multicolumn{3}{|c|}{$\begin{array}{l}\text { No. Ex-Conviots } \\
\text { having other of } \\
\text { fenses or oourt } \\
\text { records }\end{array}$} & \multicolumn{3}{|c|}{$\begin{array}{l}\text { No. Ex-Convicts } \\
\text { having no other } \\
\text { listed offenses }\end{array}$} \\
\hline & $\mathbf{M}$ & $W$ & & & $\mathbf{M}$ & 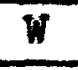 & Total & $\mathbf{M}$ & $W$ & Total \\
\hline 1 & 51 & 3 & 64 & 54 & 23 & 2 & 25 & 28 & 1 & 29 \\
\hline 2 & 14 & 0 & 14 & 28 & 6 & 0 & 6 & 8 & 0 & 8 \\
\hline 3 & 21 & 0 & 11 & 33 & 5 & 0 & 5 & 6 & 0 & 6 \\
\hline 4 & 3 & 0 & 3 & 12 & 2 & 0 & 2 & 1 & 0 & 1 \\
\hline 5 & 3 & 0 & 3 & 15 & 1 & 0 & 1 & 2 & 0 & 2 \\
\hline 6 & 1 & 0 & 1 & 6 & 1 & 0 & 1 & 0 & 0 & 0 \\
\hline 7 & 0 & 0 & 0 & 0 & 0 & 0 & 0 & 0 & 0 & 0 \\
\hline 8 & 0 & 0 & 0 & 0 & 0 & 0 & 0 & 0 & 0 & 0 \\
\hline 9 & 1 & 0 & 1 & 9 & 1 & 0 & 1 & 0 & 0 & 0 \\
\hline None & $3^{*}$ & 0 & 3 & 0 & 3 & 0 & 3 & 0 & 0 & 0 \\
\hline Unknown & 2 & 0 & 2 & 0 & 2 & 0 & 2 & 0 & 0 & 0 \\
\hline Totals & 89 & 3 & 92 & 157 & 44 & 2 & 46 & 45 & 1 & 46 \\
\hline
\end{tabular}

-Workhouse or jall sentences only 
Table 8 may give some indication why care must be taken in interpreting a one-time offender necessarily as a reformable individual. Although by far the greater number of ex-convict olients, 54, have a record of only one felony, 25, or almost half of this group have either had juvenile delinquency records or other conflicts with the law-incluaing drunkenness, disorderly conduct, nonsupport, assault and battery, larceny, etc. It 18 also very interesting to note that exactly half the number of 92 ex-convicts have ilsted jurenile delinquency or jail and workhouge sentences; Chances are exceedingly great, however, that a larger proportion than this had other records, for police records were not uniformly checked, and in some cases, not enough was known about the client to make the results too valid except in a general sense. The table may indicate, however, that the Agency is seelng the majority of these clients before they become recidivistic in committing major offenses, punishable by death, Ilfe imprisonment, or by terms Ionger than one year's duration.

Of what offenses were these ex-convicts guilty? It maj be of interest to examine the offenses, and to be alert to possible needs within the client for certain kinds of service, or to attitudes in taing help, as these 
skills in treatment might be related to the cllent's background. Although crime classifications are generally arbitrary devices, sultable for the needs of the person or agency using them, some classification is necessary for tabulation. According to Nathaniel Cantor, soclologist at the University of Buffalo, and an authority on criminal behavior, most classifications "are all too simple in that they emphasize the act and fail to take into account the individual and social contexts in which the crime arises"l, but he concedes that for statistical purposes, olassif1cation according to the type of crime 18 usable. Edwin Sutherland, Soclologist, agrees that some classification Is needed, and states that "Crimes are erequently classifled for statistical purposes as crimes against the person, crimes against property, and crimes against public decency, public order, and public justice."2 "Crimes against the State" is added as a category by Nathaniel Cantor, to include all possible classiflcations. Table 9, page 76, is based on these 4 large claseifications. Assistance in classifying the crimes of the 92 ex-convicts being studied was secured from Mr. Briscoe, Federal Probation Officer of Louisville, in addition to comparison with

\footnotetext{
I Ib1d., p. 275 .

2Edwin H. Sutherland Principles of Criminologr (Chicago: J. B. Lippincott Company, 1939), p. 21.
} 


\section{TABLE 9}

NUMBER OF OFFENSES COMMITTED WITHIN LISTED CRIME CLASSIFICATIONS

Crime Classification

Crimes Agalnst Person

Crimes Against Property

Crimer Against Morals, Public

Justice and Public Order

Crimes Against State

Parole Violation, reason not stated"

Offenses 11 sted but unknown

Military violation

Total No. Offenses
Total No. Offenses

* In each of these instances, there was a separate imprisonment, but caserecord did not state cause of parole violation.

examples given in the two text books mentioned above. Certain crimes may fall within one of several classifications, depending on local interpretation, so that the typing of the offenses above cannot be considered as static. The results, however, point to a general trend of types of offenses seen in the 92 ex-convicts. 
It 18 readily seen from table 9 that the number of offenses falls preponderantiy in the classification of "Crimes Against Property". Since the classification 1ncludes a broad range of all types of stealing, this would be natural to expect. One can assume just as great a variety of motives and just as great a difference in the degree of severity of the violation. Among the types of stealing seen were: Larceny, Housebreaking, Burglary, Armed Robbery, Conversion, Fraud, Embezzlement, Charge Attempt Under False Pretense, eto. Under "Crimes Against Person" one 11nds: Murder, Manslaughter, Shooting Without Wounding, Rape, etc. Among the "Crimes Againgt Morals, Public Justice, and Publ1c Order are: Bigamy, Violations of the Volstead or Harrison Narcotle Acts, other violations of interstate commerce, Violation of White Slavery Act, Impersonating a Federal Officer, False Swearing, etc. No "Crimes against the State"-1.e., Treason--were found among the records studied. In the above table are I1sted "Parole V1olations." Usually the offenses necessitating return to prison were given in the clients' penal record, and are tabulated according to the type of offense, but in 5 cases a new 1mprisonment, after a lapse of time, was listed as having been caused by "parole violation". Continuations of a 
last sentence beyond the parole period are not included under "Parole V1olation", as the listed offense 1tself was the cause of the extension of the prison term, and "parole violation" accompanied the charge.

Four offenses were marked "unknown", and one exconvict's claim to the Lotta Fund was based on a military charge of Desertion. Although data was not consistently secured in all releases, as to the release category, in cheoking over the schedules it was evident that by far the majority of ex-convicts were paroled or conditionally released, with a minority having completed a full sentence. The length of periods of incarceration ranged from several months to 12 years.

What lapse of time is there between the termination of the prison sentence and the beginning contact with the Agency? The statement in Clause 9 of Lotta Crabtree's w1ll Implies that the purpose of the Fund is to ald those persons who are newly discharged. By comparison of dates of ending prison term and beginning contact with the Agency, some ploture is secured of how soon the Agency is meeting the discharged convict's service and rellef needs. There 18 great valldity to the thinking adranced during the past Var, that service and help to battleshocked soldiers must not be too long delayed. Perhaps 
the situation of the ex-convict offers a parallel. It 18 difficult to suggest a recommended period of time between date of discharge and date of acceptance by an egenoy. For purposes of this study a period of 12 months was set as the outer IImit, although this may actualiy be too long a lapse of time. It was found that 62 ex-conviots out of 92 came to the Agency 12 months or less after release from prison. Of this 62, 50 were accopted by the Agency within a 2-3 month lapse between date of discharge and date of acceptance by the Agency. Thus, slightly more than $50 \%$ of the total number of ex-convicts were seen by the Agency at the time when the shock of incarceration and lmpact of adjustment to an outside world was at its most critical stage, while 62 , or $60.8 \%$ of the total number of ex-convicts were seen within a perlod of one year from date of discharge. A few cases had penal records ending in 1914, 1915, 1916, and 1925. Others were within periods of 2-3 years from date of beginning contaot with the Agency.

\section{Who is the Client?}

For a family agency the question of the 1dentity of the client under treatment is important, and consider able attention is given the selection of the person or persons for major service. Selection of the cllent for 
major contact in a famliy assisted by the agency depends on criteria of treatability and desire for service. Where two people equally wh and are amenable to help, two caseworkers are generally assigned the treatment of each of the two partners in a situation of marital difficulty. The question arises as to whother the same criteria apply to ex-convict cases. In many cases read for this study it was obvious that the ex-convict himself did not want the service that accompanied the giving of financial assistance, but that some other member of the family showed greater anxiety over the social situation confronting the exconvict than he did himself, and more actirely sought the services of the Agency. Does that mean that the caseworker should thereupon select the latter person as the client, and carry on a subsidiary contact with the exconvict himself, or does the use of a speclal fund like the Lotta Fund carry an obligation to use Ilmitations in alrecting casework help to the ex-convict--putting upon him the obligation, likewise, to maintain erequent and direct contact with the caseworker? Can indirect treatment of the ex-conviot through, say, the wife or mother, be considered as carrying out the obligation for rehabilitative help inherent in the purpose of the Fund? Perhaps, as the total plcture emerges, some guides can 
81

be established for settling these questions.

Table 10, below, gives an objective ploture of where the major contact lay in the 92 cages studied. Results were based on notations of actual numbers of Interviews, and on careful evaluation of content of interviews with regard to quality and depth of treatment. Often the caseworker airected her activity equally to both husband and wife (or ex-convict and other members of the family). This approach was especially true during the early period of 1931-1932, as has already been discussed in Chapter I.

TABLE 10

SELECTION OF CLIENT BY AGENCY AS SHOWN BY NUNBER, BREQUENCY, AND CONTENT OF INTERVIEUS

\begin{tabular}{|c|c|c|c|}
\hline \multirow{2}{*}{$\begin{array}{l}\text { Total No } \\
\text { Ex-Convict } \\
\text { Cases }\end{array}$} & \multicolumn{3}{|c|}{ Selection of Client by Caserorker } \\
\hline & $\begin{array}{c}\mathrm{Ex}-\text { Convict } \\
\text { (1) }\end{array}$ & $\begin{array}{c}\text { Spouse } \\
(2)\end{array}$ & $\begin{array}{r}\text { Family } 28 \text { unit } \\
(3)\end{array}$ \\
\hline 92 & 58 & 4 & 30 \\
\hline
\end{tabular}

It is thus seen that out of 92 cases, the caseworker maintained major contact with the ex-convict himself in 58 cases; in four cases, the contact was alrected toward the spouse (In each case, the wife of the ex-convict); in 30 cases, the caseworker directed the services 
of the Agency to all members of the family with even emphasis. Often this meant alternating interviews with husband and wife, home visits or offlce interviews in which both partners were present, etc. In the review of the actual relief handling, to be discussed in Chapter IV, the selection of the individual to recelve the actual financial assistance from the Lotta Fund will be seen, and comparison of Table 10 with Table 14, page 95 is suggested.

How did the client get to the Agency? An overall plcture of referral sources is seen in Table 11, page 83. The Family Service Organization counts as "personal", the application to the Agency by the family itself, without formal referral by any outside source. An "individual" referral is a formal referral of a ollent, by letter or telephone, by any person or persons not connected with an agency or institution respected as an agency-1.e., police department, school, social-service department of a church, etc. A referral by any of the latter sources is rated as an "other agenoy" referral. 
TABLE 11

NATURE OF REFERRAL SOURCES OF 92 EX_CONVICT

CASES STUDIED

\begin{tabular}{l|c|c|c}
\hline \multirow{2}{*}{$\begin{array}{l}\text { Total No } \\
\text { Bx-Convict } \\
\text { Cases }\end{array}$} & \multicolumn{3}{|c}{ Nature of referral } \\
\cline { 2 - 4 } & Personal & Ind1v1dual & Other Agency \\
\hline 92 & 40 & 10 & 42 \\
\hline
\end{tabular}

The above 11gures indicate that initial approach by the family itself and referrals by other agencles were about evenly divided, while 10 cases were referred by interested community people, relatives, etc. It must be kept in mind, however, that many of the "personal" applications were made at the suggestion of other agencies or individuals, al though no formal referral was made. "Other Agenoles" Inoluded the Municipal Bureau of Social Service, Community Chest, Probation Department, Federal Prisons, Aid to Dependent Chilaren Division of the State Welfare Department, etc. In latter years one sees the majority of such referrals consclously made because of the existence of the Ex-Convict Fund. In all cases referred directly as exconvicts, the request was for financial assistance and service. 
A variety of agencies in the community were used as resources for treatment of the ex-convict. Chlef among these were health agencies, Legal Ald Soclety, Municipal Bureau of Social Service (during perlod of madework programs), Kentucky State Employment Service, Salvation Army, Salnt Vincent de Paul Society. Family Agencies, members of the Family Service Association of America, in other communities were consulted for collateral information, and employers, physicians, lawyers, clergymen, schools, and relatives were seen as adjuncts in helpIng the ex-convict make a better environmental adjustment or in assisting the caseworker to a better understanding of the client. In 19 of the $92 \mathrm{cases,}$ the caseworker made some sort of contaot with the parole officer. These contacts, however, were usually not of a continuing nature, nor was there much contact maintalned on the parole officer's inltiative. It seemed that once the case was in the Agency's hands, the details of parole requirements were largely put in the background. In only a lew cases did the caseworker actually discuss parole limitations with the client. In one situation the Agency assumed parole sponsorship for the ollent and sent in his reports to the parole officer. 
Psychlatric study was completed on 8 of the 92 cases and begun in three. In a few other cases, psychlatric reports were secured from other agencles or institutions. In the cases of incomplete workup the client elther left town or was unwiling to continue going to the hospital or Mental Hyglene Clinic. Direct rocational service was noted in only seven cases, where use was made of special interviewers at Kentucky State Employment Service, of teachers in trade schools, and the State Vocational Rehabilitation Department. Direct recreational service was offered in three or four cases, with the giving of "Y" memberships and encouragement to the ex-conviot to take part in settlement house activities. In no case, however, was there continuous followup and real service in consulting with recreational workers in the client's behalf.

It was found that 18 of the 92 ex-convicts received the Ex-Conviot Fund for two separate periods of contact, and one received the Fund three separate times. In the last instance the client had had no intervening prison terms. In most of the former group of 18 cases, the case became recurrent a few months after the ending of the first contact and could almost be interpreted as a continuation of 1t. A large proportion of the ex-con- 
86

vict cases were known to the Agency at different perlods during which they were not classifled as "ex-convict" cases, and were given rellef only from the general fund. Table 12, below, shows the number of these Agency contaots had by the ex-oonvict. For purposes of differentiation, they are labeled "other contacts".

\section{TABLE 12}

NUMBER OF OTHER FAMTHY SERVICE ORGANIZATION CONTACTS BY EX_CONVICTS STUDIED

No. of other F.S.O.

0

1

2

3

4

5

6

7

8

9

10

11
Number of

Ex-Conviots

28

10

13

10

10

2

10

3

1

4

1

Total

92 
Thus we see that 28 ex-convicts had no other contact with the Agency beside period or periods of assistance with the Lotta Fund; 10 had one other contact; 13 had 2 other contacts, etc. "Other contacts" were often inquiries from other agencies about the case, other short-term services ending at the application desk, or sustained contacts over a period of months. Short-term contacts were by far the more numerous.

Some total picture of the ex-convict-his origin, background, physical and mental condition, penal record, etc.--has emerged from statistical and social data in the case-record. How he comes to the Agency, and what community resources were used in his behalf, have been noted. Now the focus will be turned on the actual administration of the Lotta Fund, the use to which the money was put, the amounts given, and for what periods of time. 
CHAPTER IV

USE OF FUND FOR RELIEF AND SERVICE

The chapter title conveys the interlinking aspects of "relief" and "service" in all financial assistance, from the caseworker's point of view. Even in situations where the client has not articulated a desire for "service" per se, it is believed that the appropriateness of the rellef given, the timing of 1 ts giving, the approach used by the caseworker, and the form in which it is given are all aspects of the giving process, full of treatment possibilities for the client and caseworker. Within the Iimits of the present study it is impossible to evaluate the less tangible areas of casework treatment in these 92 ex-convict cases--1.e., the establishment of relationshtp between client and caseworker, the degree of direct treatment of his basic difficulty through casework interviews, etc. Perhaps, however, as the ploture of the use of the Ex-Convict Fund emerges, certain treatment skills may stand out, or may be found lacking, as these skills are related to the giving process. Also, 1t may become more evident how rellef giving to a specialized 
group of individuals either is similar to, or different from, financial assistance to undifferentiated clients.

In the beginning period of 1931-1932, it was seen, as discussed in Chapter I, how the Ex-Convict Fund was usually used as a supplement or extension of the general fund. This handing arose out of necessity, produced by pressure of relief demands, and Iimitations of the Agenoy's budget. As the general relief situation in the community Improved, it was seen that gradually the $\mathbf{E}_{X}$-Convict Fund was the only source of ilnancial assistance to ex-convicts, with exceptions made on a planned, casework basis. This background must be kept in mind in interpreting the tables which appear below.

It 1s seen from table I, page 21, that a total of \$6970.05 has been spent from the Lotta Fund from 1931-1946. How has the Fund been utilized? For what 1tems of relief has it chiefly been employed? Do the total expenditures per ex-convict client indicate shortterm rellef plans or a continued plan of assistance? The extent of the rellef plan actually is a more accurate index of the type of contact--continued or brief-than the dates of beginning and ending Agency contact. These latter dates may mean that the lamily was known to the Agency for some time before the foous was put on 
the ex-conviot, or activity may have extended after the ex-convict left the family, and casework was continued with the rest of the family.

From Agency bookkeeping records, the total expenditure from the Lotta Fund for each of the 92 exconvicts was given. From this list of relief totals, the following table was arawn up to give a plcture of the amounts of financial assistance given.

TABLE 13

TOTAL AMOUNTS OF LOTTA FUND USED FROM 1932-1946

$\begin{array}{rr}\text { Range of Relief Totals } & \text { Number of Ex-Convicts } \\ \$ 1-\$ 9 & 9 \\ \$ 10-\$ 24 & 20 \\ \$ 25-\$ 49 & 23 \\ \$ 50-\$ 99 & 17 \\ \$ 100-\$ 199 & 14 \\ \$ 200-\$ 399 & 8 \\ \$ 400-\$ 595 & 1\end{array}$

Total

92

It is evident from the above relief figures that the majority of the ex-convict clients recelved less than $\$ 200$ total rellel per family, with only 8 recelving between $\$ 200$ - $\$ 300$, and one client recelving a total of 
91

\$523.71. Th1s client was assisted from $12 / 15 / 30$ to $11 / 10 / 32$, although the Agency's general fund was used after June, 1932, when the Lotta Fund was overdrawn. Over half the 92 families received less than $\$ 50$ total rellef from the Fund.

From the 92 cases read, information was checked a to the rellef category in which the assistance from the Lotta Fund to the cllent fell. The Agency 18 considering eliminating the category "supplementary", as it is a relative term and often misleading. One client may receive more "supplementary" assistance than another who receives "maintenance". In the years of worst economic deprivation, a "maintenance" plan may have meant a $\$ 2.50$ weekly food order and $\$ 10$ monthly rent check, w1th no coverage of other necessities. Therefore, for the pur pose of this study, only the category "maintenance 1tems" is betng considered, regardless of whether at the time of contact the caseworker considered the rellef as supplementary or as meeting most of the maintenance needs. Considered as maintenance 1 tems are: food, rent, cloth1ng, ut1lities, fuel, etc. Whenever these items were given on a planned basis, over a period of at least two or three weeks, the category "maintenance items" was checked. If one or more of these 1tems or any other 1tem 
92

was given as an emergency measure for one occasion and recognized as such by client and caseworker, the category "emergency relief" was checked. "Special items" would be items given outside the general maintenance plan, and having a purposive intention--1.e., tools for a specific job, a "Y" membership, a suit of clothes when not given in connection with a maintenanoe plan, etc. The information on the above rellef categories was checked and reviewed, and from the cheokings it was seen that 81 exconvicts out of 92 rere assisted with maintenance 1 tems from the Lotta Fund. The individual plans varied from that of supplementing other income with one or two maintenance items-especially during the early period when income consisted of rellef from the general fund, or inadequate wages of some member of the family-to a coverage of all of the maintenance items with the Lotta Fund. In the latter cases, the relief plan was generally one of short duration-lasting only a few weeks or, at most, a few months. In 24 of. the 92 cases, the ex-convict was assisted with special 1tems, apart from the general rellef plan, or during a recurrent contact. Such items included: funds for transportation to plaoe of legal residence; special Christmas gifts; funds for plowing cost and for seeds; replacements in dishes, utens118, bedaing, etc; 
moring expenses in order to locate in a more desirable nelghborhood; money for a driver's license, part of a cab uniform, eto; union dues; Y.M.C.A. membership; money for glasses or dental work; funds for carpenter's tools, drawing supplies, for part of cost of repair of artificlal leg, and similar needs. In one instance, the Lotta Fund was used to purchase clothing to send to the ex-conviot after he had already arrived at his place of legal residence. In $81 x$ cases the relief plan was entirely one of assistance with special 1 tems for spec1f10 use, and was a matter of one or two occaslons of rellef-giving. Three ex-convicts were given emergency assistance at application desk in situations that were apparent from the beginning as being of short duration - for example, the situation of the man who had a definite job to which to report, and needed emergency assistance one time for food until he could draw a pay. In seven of the 92 cases, the Lotta Fund was used to make wage-relief payments on the Agency's made-work program, which lasted only a short while in the early thirties. In one of these instances, the payments were actually to the ex-convict's son, but the caseworker reasoned that his employment would benefit the whole family situation and make a more agreable home life for the ex-convict. In two cases, part of the money 
given was on a loan basis, and in one case there was partial repayment.

Did the caseworkers generally seem to trust the ex-convicts with cash rellef? Table 14, page 95, shows at a glance how the relief was handled - whether by cash, requisition, or combination of methods, and whether it was given, for the most part, directly to the ex-convict, to his wife, or handled as was the casework, with the family as a unit. Often the check was malled to the family, or requisition given to whomerer came to the off1ce. Sometimes the caseworker made a special point of giving the cash to the ex-convict himself, as in the case where the caseworker decided to give the money to the ex-convict "so he might carry it himself". (This same client later absconded with a large sum of money from an Individual, outside the Agency.) Giving cash to other members of the family beside the ex-convict, however, did not preclude casualties to the grant, as in the case of the caseworker's giving the husband and wife together a sum of \$20 for furniture. The wife reported a short time later that her husband, a prior deserter, had left again with the money and without having purchased any furniture. 
TABLE 14

CHIEF FORMS OF RELIEF FROM LOTTA FUND AND CHIEF RECIPIENTS OF FUND IN 92

EX-CONVICT CASES

\begin{tabular}{|c|c|c|c|c|c|c|}
\hline \multirow[t]{2}{*}{$\begin{array}{l}\text { Total No. } \\
\text { Ex-Convicts }\end{array}$} & \multicolumn{3}{|c|}{ Chief form of Relief } & \multicolumn{3}{|c|}{ Chief Relief Recipient } \\
\hline & $\overline{C a s h}$ & $\begin{array}{c}\text { Requis1- } \\
\text { tion" }\end{array}$ & $\begin{array}{l}\text { Combi- } \\
\text { nation }\end{array}$ & $\begin{array}{l}\text { Ex-Con- } \\
\text { v1ct }\end{array}$ & $\begin{array}{l}\text { Family } \\
\text { as unit }\end{array}$ & Spouse \\
\hline 92 & 49 & 28 & 15 & 65 & 22 & 5 \\
\hline
\end{tabular}

- Category includes rellef check malled to landlord, or relief not given as cash or check directly. to family.

It $1 \mathrm{~s}$ suggested that the above table be compared to table 10, page 81 , as certain differences are apparent between the chlef focus of treatment and selection of person or persons to handle rellef funds. Although table 10 shows that the caseworker directed her contact, In 30 of the 92 cases, to the ex-convict himself, when it came to relief handling, she gave the money direotly to the ex-convict in seven more cases than clted in table 10, column 1 , and in 8 less than in column 3 of the same table. Th1s may indicate a tendency to feel that the Lotta Fund, designated for the ex-conviot, should, whenever possible, be given directly to him. It must be remembered that in giving rellef to the "family", 
often it was given to the ex-convict himself, although not as a regular plan. Relief, however, was given in 5 cases to the wife of the ex-convict, while treatment was directed to the wife in 4 cases. The five cases in which the wife was the reciplent present some variation of motives in such selection. For example, one case represented a long prior contact with the wife, and the entire treatment and relief plan was continued with her rather than with the ex-convict, whom he had just married. In another case, the ex-convict seemingly purposely evaded contact and made it diffloult for the caseworker to reach him. In two cases, the ex-convict was a deserter, and relief was continued with his wife - although later thinking discarded use of the Lotta Fund whenever the exconvict himself was out of the family setting. In another case, the Lotta Fund was used as a supplement to the wife's earnings as a domestlo, and since she handled family Iinances, the relief plan was made with her.

It 18 seen, also, that cash-relief was generally used in over half the 92 cases, that a combination of cash relief, rellef by requisition, and relief in kind (1.e., coal or milk) was given in 15 of the 92 cases. In 28 cases, the ex-convict or his family experienced very few occasions of handling cash rellef. In these 28 cases, 
rellef was given in the form of a voucher, exchangeable at specifled grocerles for lood, clothing, etc. or checks were malled to landlords, utility companies, rather than the payment given in cash to the family.

The relief plan with regard to the ex-convict cases seemed to have more relation to general practice In the Agency at the time, rather than to specific needs of the ex-convict. In other words, the giving of relief by requisition was almost entirely present during the early thirties, when cash rellef to all clients was still the exception to the rule. As the Agency more and more adopted cash relief, assistance to the ex-convicts almost uniformly fit into this plan also. There are some Indications, though, that the caseworker gave serious thought to the form of rellef best adapted to the needs of the ex-convict. In 1936 the comment was made on a case that the Executive Secretary suggested that "no Iump sum be given" the client unless "under close supervision". Later, if the client proved he cowld "stand on his own", more money could be given him. In another case, the supervisor suggested to the worker that a meal ticket be given to the cllent instead of cash rellef, as the client was addicted to alcohol. When the meal ticket was offered the cllent, he became angry and refused assis tance. 
In surveying the entire period of the use of the Lotta Fund, one sees flexible adaptations in rellel giving from year to year. Partly, these varlations are accountable to changing philosophy of casework and relief-giving and are a healthy growth process. Partly, they seem due to lack of cohesion in bringing together the total thinking about meeting the needs of the specialized group of ollents, known as "ex-convicts". It has already been mentloned that in one instance, the decision was made that rellef for the requested item could be met only by the Lotta Fund, because of the questionable nature of the request; in a similar situation, it was decided that the rellef should instead come from the general fund. In the early period of 1931-1932, the Lotta Fund was a welcome substitute for dwindling relief funds, and interpretation of its function and origin was seldom given the client. A period of experimentetion and "trial and error" use of the Fund followed, as the acuteness of the general rellef need subsided. In one case the casoworker considered giving money from the Lotta Fund a an allowance to the daughter of the ex-convict, in order to ease family tension. The Fund, again, was used in IImited amounts of $\$ 25$ to meet specialized needs in sereral more families of ex-convicts already belng assisted 
by the Agency. One sees the term "exploratory period" used more frequently, and cases otherwise refused assistance, were taken "on trial" by using the Lotta Fund. Casualties occurred more frequently-in a few instances, the client disappeared with cash given in an early contact, or gave misleading information to the caseworker as to his income, job arrangements, etc. The caseworker grew in alertness to "psychopathic" tendencies in individual clients. Interpretation of the source and function of the Lotta Fund was generally given the reciplents. As the development of the use of the Fund advanced to recent years, a certain self-confidence in the handling of the Fund emerged, as well as a great deal more articulated questioning about the pros and cons of 1 ts use. If the client was not "hopeful", the caseworker was, on the other hand, better able to predict possible disappointing results. More definite time limits, of "not longer than a month to evaluate" potentialities for rehabllitation, are evident in the case records. Also, there is recognition that, with extremely unstable individuals or individuals having lived through very trying experiences, the Family Agency may have a right, within 1ts funotion, to meet emergency needs without expectation of recognized rehabilitation--at least with a limited 
number of clients. Hence, relief from the Lotta Fund is occasionally given, accompanied by the caseworker's thinking in granting relief in this way.

The total rellef amounts per ex-convict family are, as has been seen, relatively low in comparison to other rellef cases, where often the same amount is given monthly and on a much more prolonged basis. As has been discussed in Chapter III, a little more than half the total number of ex-convicts assisted from 1932-1946 were given relief within a period of a few months from dates of release, with still 30 of the total number's being accepted for assistance after more than a year's freedom. Comments in a few records indicate that caseworkers and supervisorg are doing much more thinking as to whether more definite criteria should be established regarding recency of the prisoner's release in relation to acceptance for assistance from the Lotta Fund. Also, questions have been raised as to the client's eligibility for assistance from the Fund when a recurrent application for help has been made, with no intervening prison record.

A few additional comments should be made about some of the caseworkers' sincere efforts to make the environmental situation easier for the ex-convicts, even though objective end results cannot be measured within 
101

the IImits of th1s study. Noted were several illustrations of providing better living quarters for the exconvict and his family; of trying to help the client restore his citizenship rights; of securing "adopted parents" for an unattached young man; of helping the client establish a work record by cooperation with a sheltered workshop, where the cllent could bulld up a work recommendation; of getting helpful information from other agenoles regaraing the client's mental, physical and social background, of giving marltal counseling to ease readjustment straina, etc. Some of the results have been discouraging; many can probably never be measured. A follow-up study on selected cases may be an outgrowth of this study, and point up the depth of the work done with the ex-convict group. 
SUMMARY AND CONCLUSIONS

In recapitulating some of the findings of the present study of 92 ex-convicts assisted by the Lotta Fund at the Family Service Organization from 1932-1946 several facts stand out. First, until the present study was made, there has been no drawing together of the total Agency's experience in dealing with the ex-convict group and in setting up guides to establish eligibility of cllents for the Lotta Fund. In relation to the total Agency's service and relief program, the ex-convict group represents but a small minority of the total Agency caseload, and 1t $1 \mathrm{~s}$ not unusual to expect att1tudes of confusion, lack of practical knowledge about conviction, imprisonment and release procedures, and a lack of sharpness in defining eligibility requirements. At the same time, the lack of focus on this group has a healthy aspect in that, rightfully, the ex-convict is not put into too rigld a category. After all, actual treatment should be directed to the cllent as a person, and not as a different species of human being, categorized as "ex-convict". Involuntarily, the tag may persist and become a stigma even in the minds of trained caseworkers, if too much 
emphasis is put on the social status of these clients. On the other hand, the Agency has the administration of a Iimited income for the benefit of those persons recently discharged from prisons, and limitations in ol1gibility requirements and in some aspects of treatment need defining in order to narrow the number of reciplents.

The clause 9 of Lotta Crabtree's will does not give too many guides in interpreting the function of the Fund, in specific terms. It would appear that assistance is recommended for recently discharged men and women convicts, as the statement implies in the will: Those "who find themselves after their release in any almost helpless condition in which to begin the world anew." Although it is extremely difficult to set up arbitrary time IImits between date of release and date of seexing help, it would seem that a gap of not longer than one year would indicate something of the cllent's capacity to adjust, would give clues as to the difficulties he faces in readjustment to society, and still would be a period within reasonable distance from date of release. Since the will does specify the service to be rendered in helping the client find employment, the ripest perlod for doing this, for linding sympathetic assistance from employer groups, etc. would appear to be during the period 
closely following the cllent's release. A year's perlod of time also would give seasonal workers four seasons in which to Ind work opportunities suitable to their respective skills. Of course, flexibility in evaluating perlods beyond a year from date of release as making a client eligible for help from the Lotta Fund would be needed. Old prison records of the client certainly inIluence the caseworker's approach and treatment in all cases, but would not make him thus eligible for assistance from the Lotta Fund. The function of the Lotta Fund, because of its limited amount, would more I1kely be assistance for those clients still "In shock" from recent imprisonment. In evaluating a client's acceptance for help from the Lotta Fund it would seem logical, therefore, to consider the client's problem of adjusting to his family and the community, after incarceration, as the precipitating factor in his coming to the Agency, rather than incidental to other problems. Available material from other agenoles indicates that the Lotta Fund is chlefly used for short periods of time, to ease the first shock of leaving prison $11 f e$, and that when prolonged needs are presented, referrals are made to appropriate agencles in the community equipped to handle long-time dependency. The Family Service Organi- 
zation has also demonstrated this bellef in 1 ts praotice, and definite recommendations elther to continue the relief plan from the general fund or to refer the case to a public agency in the community have appeared in cases where the need extends beyond a few months. The majority of rellef totals per ex-convict family fall in a range from $\$ 1.00$ to $\$ 50.00$. It would seem wise, therefore, to consider reasonable time IImits to use of the Lotta Fund, within a range of 2-3 months, with definite case evaluation and recommendations at the end of that period, either to make a new relief plan with funds drawn from the Agency's general fund, or to transfer the case to another community Agency.

What is an ex-convict? $A_{s}$ an individual he or she 18 no different from any person who 18 a victim of poor environment, lack of childhood security, or other unfarorable developmental influences. His lack of adjustment happens to be manifested by aggressive acts agalnst soclety. Further, the acts he has commltted not only fall into categorles of punishable crime, but he also happens to have been apprehended, whether by accident or unoonsclous wish on h1s part. Another individual may carry on destructive dealings under the cover of "good business" and escape legal punishment. In a 
narrow sense, however, some defining of an "ex-convict" is necessary further to establish his eligibility for a special fund. Should not the question of whether he is an ex-convict after he has been released from prison, reformatory, or penitentiary or whether he can be so consldered after only jall or workhouse sentences be settled? Early in the history of the use of the Lotta Fund at Family Service Organization, the statement was made that only individuals having had prison, penitentiary or reformatory sentences were eligible for the Ex-Convict Fund; later, this requirement was apparently changed or overlooked, as three of the 92 ex-convicts assisted had had only jall and workhouse sentences. By dictlonary def1nition, a convict is "one found guilty of orime", and "crime" is defined as "any grave offense". Again, the caseworker may seem to be thrown into having to use subjective interpretation of the relative seriousness of the offense committed. Beoause practice in other agencies using the Lotta Fund has been, by rirtue of the very function of these agencies, to assist those discharged from prisons, and since the $11 \mathrm{mited}$ amount of the Fund requires selectirity in cholce of eliglble clients, it would appear that the Agency's original I1mitation of aid 
to those discharged only from prisons should be reinforced. The existence of jail or workhouse sentences appears all too common an experience of many clients of a social agency, and the problem of selectivity would be greatly complicated if all were considered potentially eligible for such a small source of assistance as the Lotta Fund. Finally, there are the actual words in Lotta Crabtree's w1ll, that assistance should go to "both men and women, who suffered punishment therefor in our state prisons and reformatories". One wonders if the limitation "state prisons" needs further refinement; however, practice in other agencies who sent material indicates that both state and federal prisons were settings for imprisonment of men and women assisted.

What special skills should the caseworker have who deals with an ex-convict Can the service flt into the function of a private family agency? It seems that a private family agency is in an excellent position to give service to such a group of individuals. Its emphasis on understanding motivations of behavior, 1ts non-judgemental attitude, its tendency not to categorize individuals, and 1 ts employment of psychiatric consultation, all seem to provide the 1deal setting for casework with those individuals who have had damaging experiences. There is 
evidence that more emphasis needs to be put on acquiring a better acquaintance, on the part of the caseworker, with practical knowledge about the client's conviction, his prison IIfe and attitudes toward it, the method of his release, the requirements of his release, the category of h1s crime. Since the majority of the 92 ex-convicts were convicted of "Crimes Against Property", does not the caseworker need to evaluate carefully these cllents' attitudes toward money, toward taking assistance, and to consider the best method and form of assistance? It seems that deeper exploration into the cllents' attltudes toward money and possessions might lead to more definite evaluation and recomendations regarding the method and form of rellef to be given. Should he be given only small sums of money at a time? Should only requisitions be given to certain clients? These questions can be answered individually after the total picture of his offense, its motivation, and its punishment can be Btudied more deeply.

As the caliber of casework skills increases in the Agency, whenever possible, consultation service should be used on a group of ex-convict cases, as teaching material for the entire stafe. In this way a proper perspective on the problems of the ex-convict can be gained, 
much as study of the unmarried mother points up many common problems seen in this group of clients. Also, whenever possible, the advisability of selecting a man caseworker for certaln ex-convict clients should be considered, for reasons previously mentioned in Chapter I. Should there be residence requirements for assistance with the Lotta Fund? At a time when considerable thinking is being done about the Inadvisability of adhering too closely to settlement requirements, it seems that the Agency's practice in I1miting the Lotta Fund to those living in Loulsville, not necessarily legel residents, is wise for such a limited group of clients. So far, the majorlty of the ex-convicts already assigted have definite residence, or ties, to Loulsville or Kentucky. If the trend goes more rapidly in to increased application by transients or "drifters", more limiting requirements may be needed. Verifloation of imprisonment and prison evaluation of the ex-convict's record would seem much more useful criterla for acceptance than the fact of legal residence. Such verifications would appear to be necessary parts of the application process. If an agency exists in the location of the ex-convict's legal residence, and there seems no particular reason for his remaining in this community, it would seem that 
the Ex-Convict Fund could be used for transportation to his legal community, after assistance there has been arranged for.

It seems obvious that for clearer focus on mutually delined goals and for better client-worker participation, derinite interpretation of the Lotta Fund, and its object, should be given the ex-convict client. What about the matter of the client's "hopefulness" in accepting casework help as a criterion for assistance from the Lotta Fund? Much weight 18 throw to evaluation of a cllent's abllity to take help in considering applications of undifferentiated clients. Yet there seems to be validity in thinking that a small group of cases may always be taken on by a private family agency, even where much change within the individual is questioned. There are individuals in every community who recurrently need emall "I1fts", who may never progress to much greater stabllity, and who fall "between agencles" In being eligible for assistance. The Family Service Organization has at times filled community gaps in resources for such indiriduals. Could not the small number of ex-convicts coming to the Agency be considered a justiflable clientele for legitimate exercise of this function--a function resting on the premise that brief, 


\section{1}

non-judgemental, warm contacts even without too much hope of rehabilitation gives to the individual one experience that differs from the reception he usually meets from the outside world? Caseworkers have been surprised at the evident treatment values of such contacts, as brought out in recurrent applications and by articulate expressions of the workers' helpfulness. Wise IImlations in evaluating emplojment records, in veriflcations of jobs and income, as well as alertness to the client's need to make himself appealing to the worker, of course need to be ut1lized. Perhaps a followup study might be profitably made of the eventual adjustment of these individuals who are briefly seen and alded. In conolusion it would be helpful for the Agency to set down again in a definite written statement, the criterle for assisting ex-convicts from the Lotta Fund. Such a statement would include a requirement to verify the imprisonment and to secure from the prison or from a rellable agency as much information as posible about the offense, the length of imprisonment, the terms of release, the prisoner's adjustment and about the prisoner's social situation. Pending recelpt of this information, emergency assistance may need to be given. The statement would include recommendations as to the lapse of time be- 
tween release and application to the Agency to consider In acceptance of the case as well as the requirement that the term be one served in prison or reformatory. The decision that there should be no residence requirements except that the ex-convict be resiaing in Loulsville at the time of contact should be set down. Time Iimits for assistance would be suggested, with evaluation of the client and treatment at the end of the per1od. The Agency already requires monthly reports on each case, as has been discussed, and this practice is extremely helpful.

A follow-up study of a smaller range of cases of ex-convicts assisted by the Lotta Fund would be very valuable from the point of view of casework evaluation of methods of establishing relationship with the client, of developing treatment through individual interviews, and of results of treatment as observed in the client's abllity to take hold of his problem and move toward some adjustment. Specialized treatment skills might thus be stimulated and predictability of results expected from assistance to this group might be sharpened. Such Information would be of great value at a time when there is much shifting in thinking as to the best ways to eval- 
113

uate oriminal behavior and to treat 1t. The service to a specialized group of clients, known as "ex-convicts", once regarded as a kind of appendage to the total function of the Agency, may thus be on Its way to become less frustrating, and richer in opportunities for casework, once it is viewed with more realism and acceptance. In this way it will also fulfill the spirit as well as the legal requirements of the benefactor, Lotta Crabtree. 
APPENDIX

SCHEDULE USED IN ANALYSIS OF

CASE RECORDS

\section{Identifring Information}

Name

Case No.

Race Sex

Age

Religion

Birthplace

No. of Children Residence.

II Family Status of Ex-Convict III Soc1al Service Ex-

A. Married Couple change Clearings

B. Common-law Couplo

C. Unmarried Couple.

D. Single

E. Divorced

F. Separated

$G$. Widowed

H. Unknown

IV Education and Training of Ex-Convict

A. El ementary

B. High School

C. College

D. Other formal training

E. Education unknown

F. Trade or special skill acquired through experience

G. Unskilled worker

$\checkmark$ Habitual Living Arrangements

A. Residence chlefly in hotels

B. Residence chlefly in rooming houses

C. Residence chlefly in house or apartment

D. Set-up: Alone_With family

W1 th friends Unknown

VI Mental and Physical Status of Ex-Convict

A. Diagnosed Mental IIIness 
B. Diagnosed Physical Illness or Handicap

VII Penal Record

A. Prison Offenses Length \& dates Name of Terms of of prison stay Institution Release

1.

2.

3.

4.

5.

6.

B. Other Offenses

1.

2.

3.

4.

5.

6.

C. Has incarceration been officialiy verifled? How?

D. Does case-record contain adequate information from penal institution? evaluation of convict adjustment

Prison estimate of potentlality for rehabilitation

VIII Emplerment Record

A. Regular Employment

$\begin{array}{llll}\text { Place of } & \text { Types Dates Wages } \begin{array}{l}\text { Reason for } \\ \text { Discharge }\end{array}\end{array}$




\section{6}

B. Casual Employment

C. Employment record unknown or too incomplete to be valid

IX Mechanics of FSO "Ex-Conv1ct" Contact

A. Sources of in take:

1. Personal application

2. Individual application

3. Cilent referred by Other Agency Name

B. Nature of hequest by client or referral source

C. Dates of contacts as "Ex-Convict Funa" case

D. Number of all other FSO contacts

E. Contact chiefly with Ex-Convict

With spouse

As a family unit With relative

$X$ Administration by FSO of "Ex-Convict Fund"

A. Principal use of funds:

1. To cover maintenance items

2. To cover special need or needs

$$
\text { Items }
$$

3. To cover wage-relief payments

4. To cover emergency needs for short contact

5. As a loan Items

B. Rellef negotiations chiefly with Ex-Convict directly. With Spouse

c. Form of relief: Chlefly cash Requisition In kind

D. Amount of Ex-Convict Fund used 
XI Use of Community Resources for Ex-Convict during Fso Contacts

A. Psychiatric consultation

Agency

B. Vocational consultation

Agenoy

C. Recreational fac1lities

Agency

D. Consultation with parole or probation officer

E. Other Agenc1es or Ind 1viduals

XII Comments: 


\section{BIBLIOGRAPHY}

Rourke, Constance. Troupers of the Gold Coast or the Rise of Lotta Crabtree. New York: Harcourt, Brace and Company, 1928.

Cantor, Nathaniel F. Crime and Socjety. New York: Henry Holt and Company, 1939.

Sutherland, Edwin H. Prineiples of Criminelogy. Chicago: J. B. Lippincott Company, 1939 .

Attorney General's Survey of Release Procedures. Prisons. V01. V. Leavenworth Kansas: Federal Prison Industries, Inc., Press, 1940.

State of New York, Leglslative Document (1946) No. 29. The One Hundred and First Annual Report of the Prison Asgoclation of Nex York. Albany: Williams Press, Inc., 1946.

Schmideberg, Melitta. "Can Criminals Be Analyzed" Journal of Soctal Cesework, V. XXVIII, No. 3. March, 1947 .

Prinz, Marian. "A Study of the Family Service Organization, Loulsville, $K y$. In Reference to Intake 1884-1940." Unpublished Master's Thesis, University of Loulsville, 1941.

El11s, Bernice. "The History of the Famlly Service Organization, 1884-1939." Unpublished Master's Thes1s, University of Loulsville, 1941. 